\title{
Institutional Independence of Federal Courts in Ethiopia: Observations
}

Aron Degol *

\begin{abstract}
As one of the three organs of government, the structure and powers of the judiciary are enshrined in the 1995 FDRE Constitution. Articles 78 to 81 of the FDRE Constitution and other laws deal with the independence of the judiciary, judicial powers, jurisdiction of courts and appointment of judges. The principles enshrined in these laws include the independence of the judiciary which has two dimensions, i.e., individual/professional independence of judges and institutional independence of courts from other organs of the government. This article focuses on the legal regime and the practices with regard to the institutional independence of federal courts in Ethiopia that are inconsistent with the constitutional guarantee of judicial independence which includes empowerment in the preparation of budget, the process of budget approval, level of autonomy in using revenue generated through court fees, independent administration of support staff at courts, procurement processes and property administration. The article analyzes the relevant laws and discusses comparative experience on these avenues of concern and calls for due attention to the gaps that should be addressed.
\end{abstract}

\section{Key terms:}

Judicial independence $\cdot$ Federal courts $\cdot$ FDRE Constitution $\cdot$ Ethiopia

DOI http://dx.doi.org/10.4314/mlr.v14i2.5

This article is licensed under a Creative Commons Attribution-

NonCommercial-NoDerivs (CC BY-NC-ND)

Received: 26 July 2020

Accepted: 14 December 2020

\section{Suggested citation:}

Aron Degol (2020), 'Institutional Independence of Federal Courts in Ethiopia:

Observations' (in Amharic), 14 Mizan Law Review 2: 310-340

* Aron Degol (LLB, LL.M, MBA), Lecturer, St. Mary's University, Email: arondegol416@gmail.com ORCID: https://orcid.org/0000-0002-6035-2222 


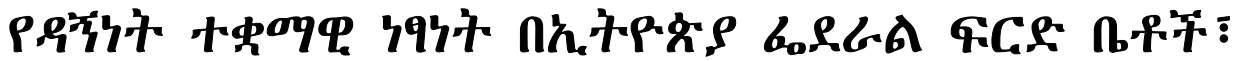

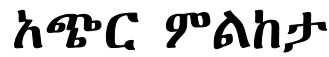

หล"3

“b.jh,

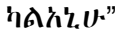

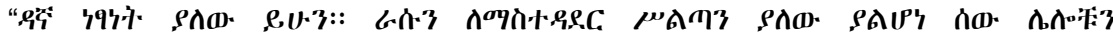

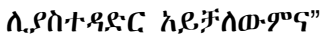

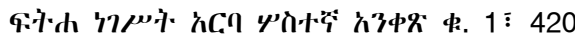

"A Judge must be a free man, because he who has no power over himself has no power over others"

Fetha Negest CH. XLIII Sec. I

\section{hU\%C中, 故 (Abstract)}

б039

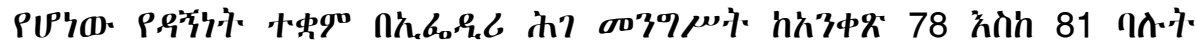

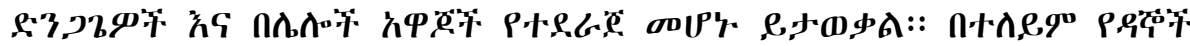

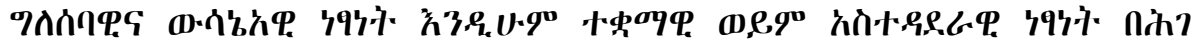

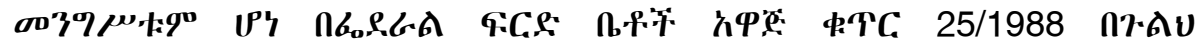

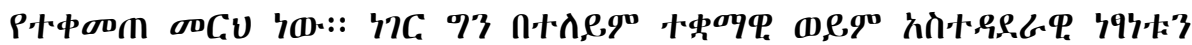

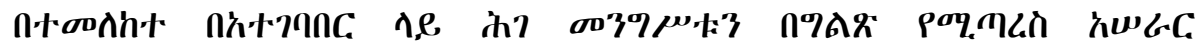

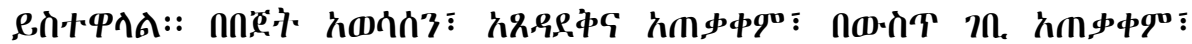

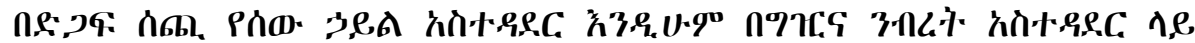

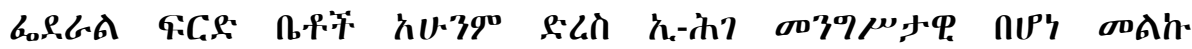

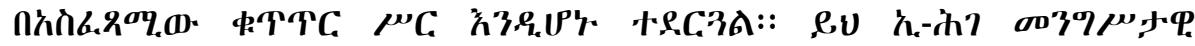

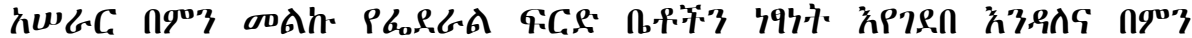

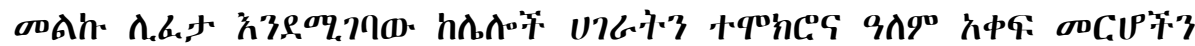

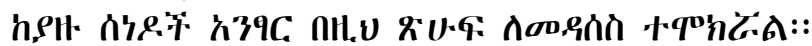

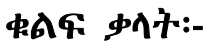

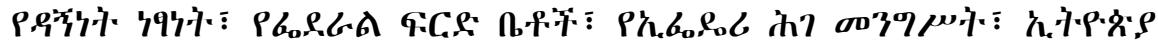

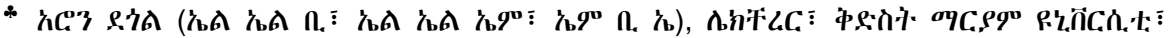

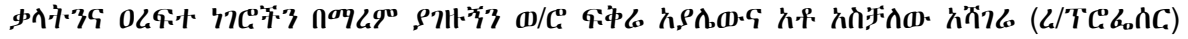

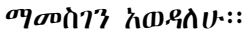

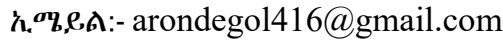

ORCID: https://orcid.org/0000-0002-6035-2222 
\%оח, $\rho$

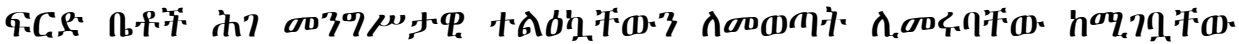

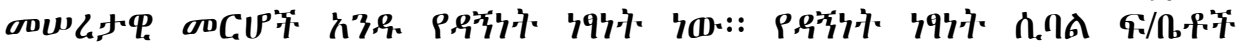

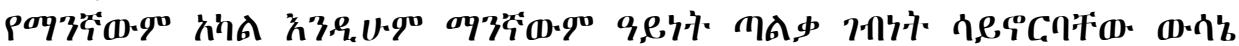

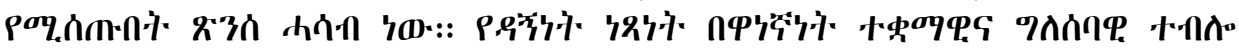

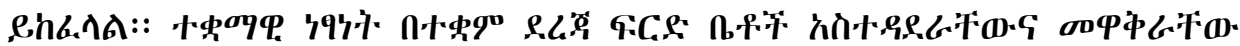

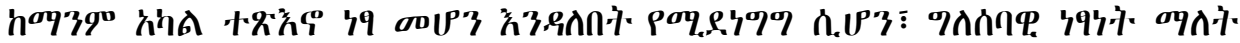

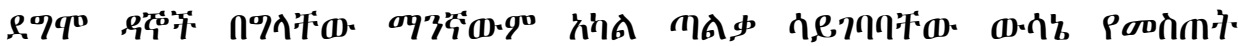
w

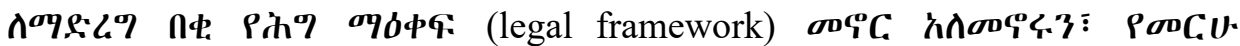

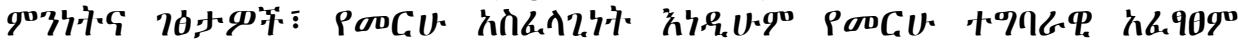

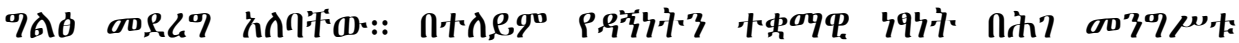

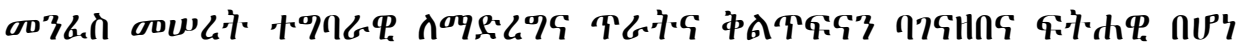

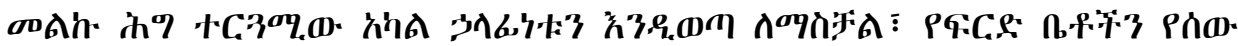

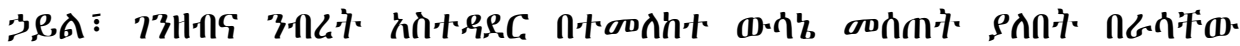

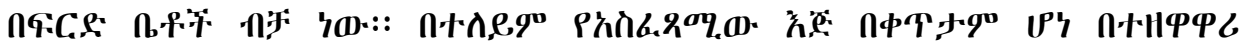

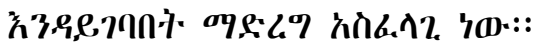

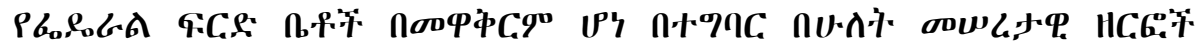

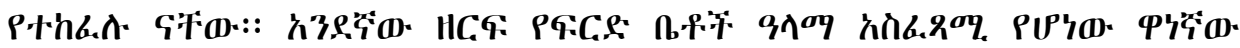

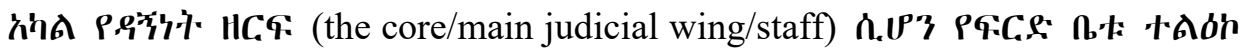

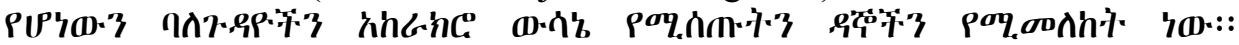

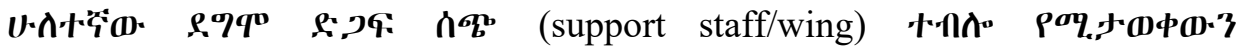

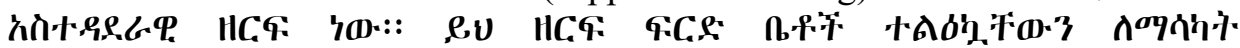

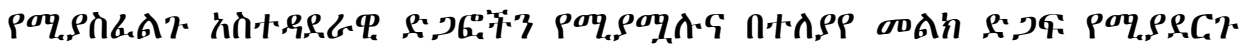

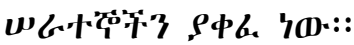

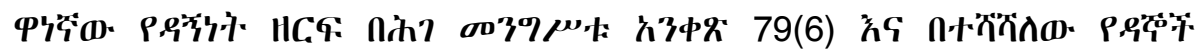

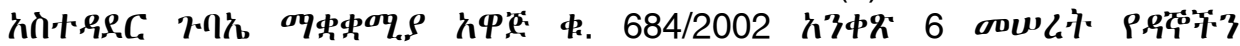

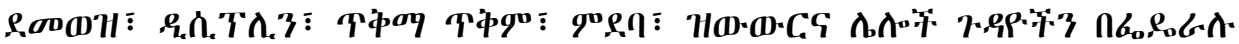

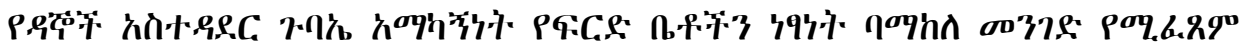

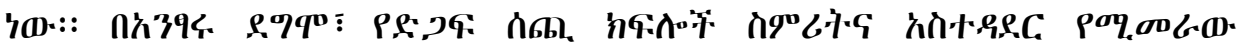

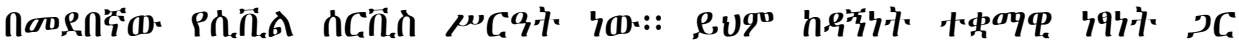

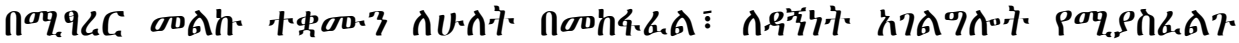

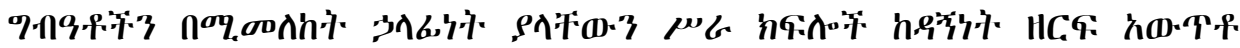

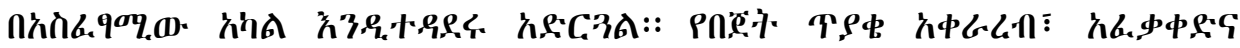

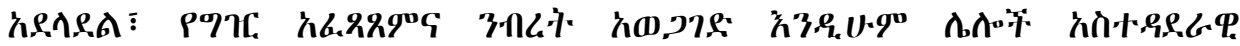

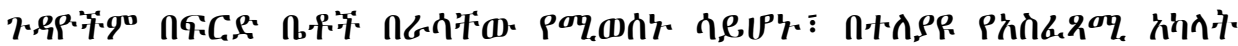

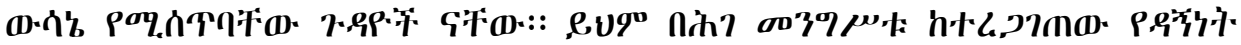

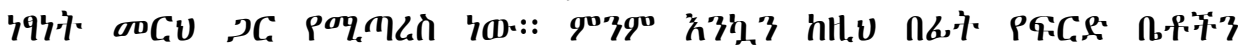

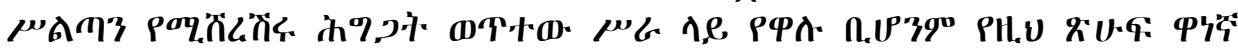

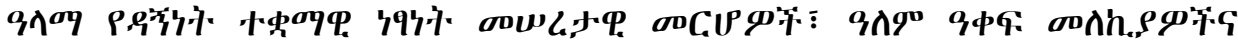

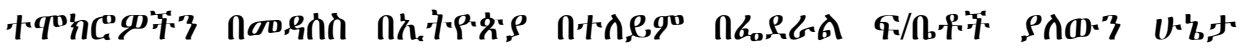

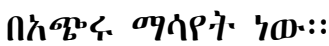




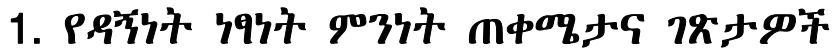

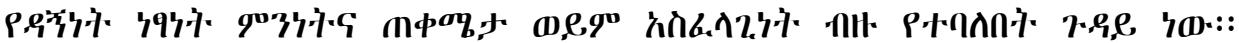

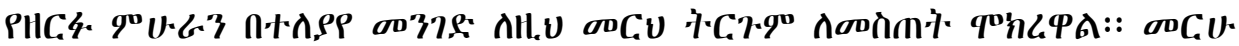

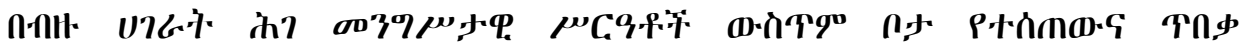

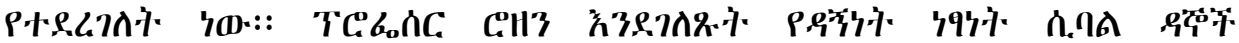

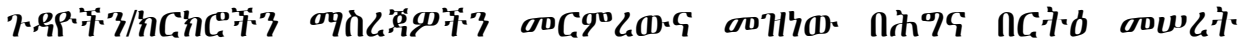

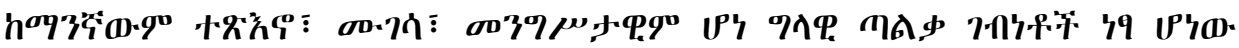

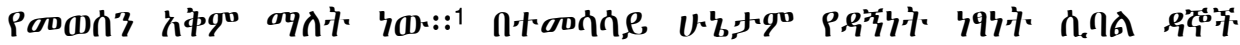

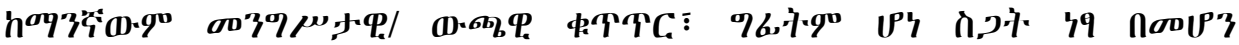

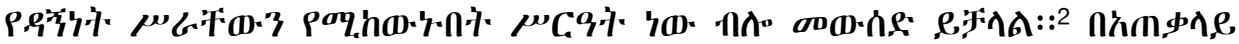

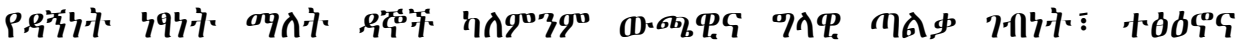

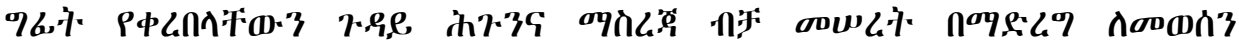

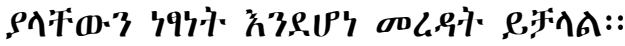

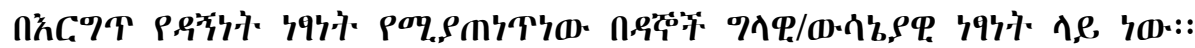

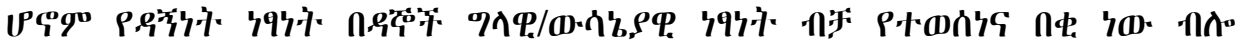

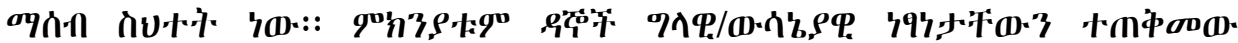

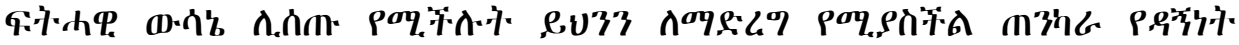

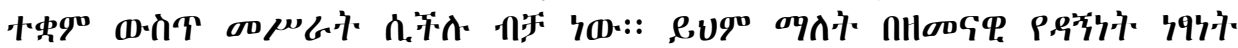

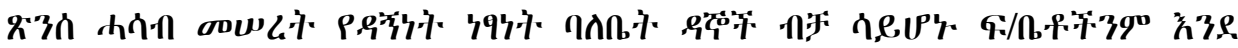

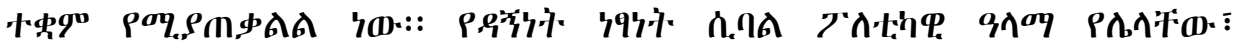

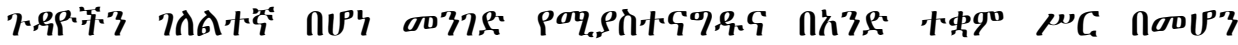

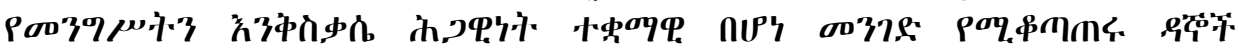

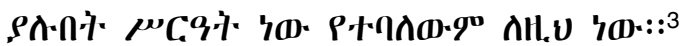

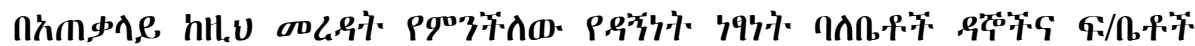

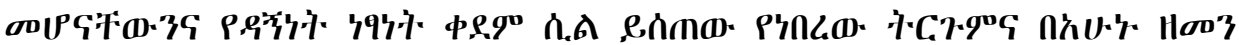

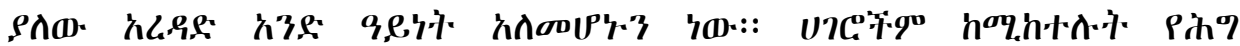

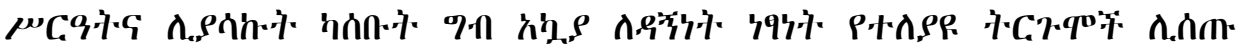

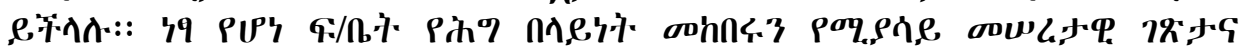

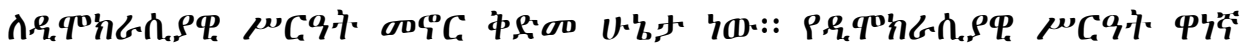

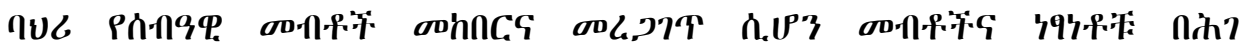

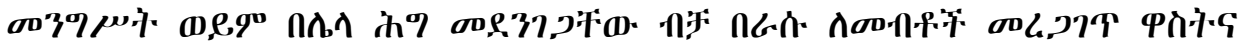

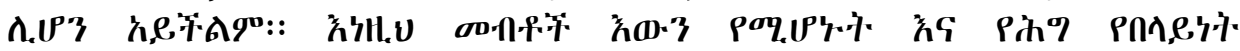

${ }^{1}$ Keith S. Rosenn (1987). The Protection of Judicial Independence in Latin America, International American Law Review Vol. 19, No. 1.

2 Penny J. White (2002). "Judging Judges: Securing judicial independence by use of judicial performance evaluation", Fordham Urban Law journal, Vol. 29

3 Christopher Larkins (1996), "Judicial independence and Democratization: A theoretical and conceptual analysis", American Journal or Comparative Law, Vol. 44 \# 4 


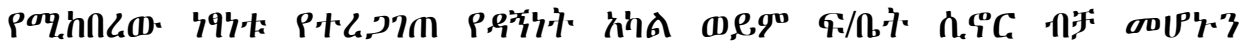

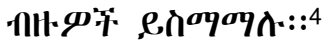

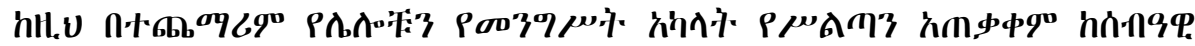

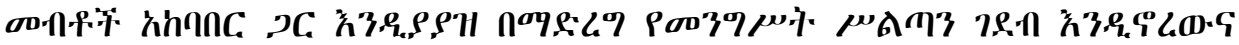

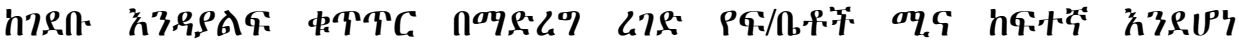

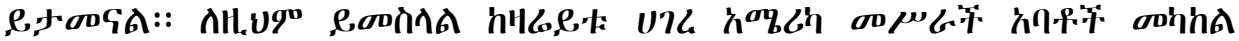

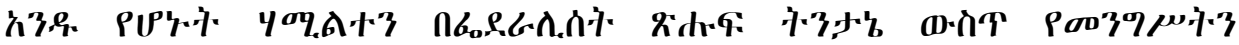

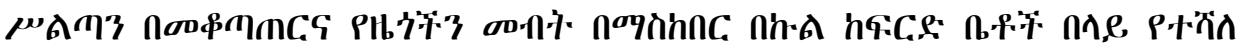

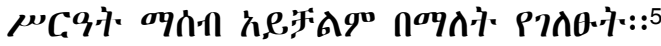

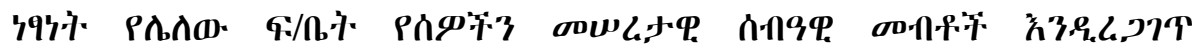

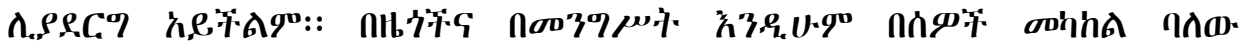

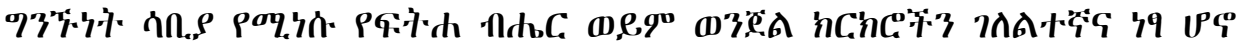

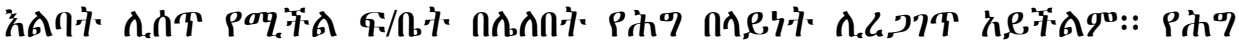
Pחл,

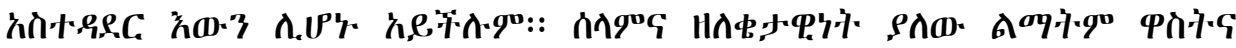
h,eqLad.90:

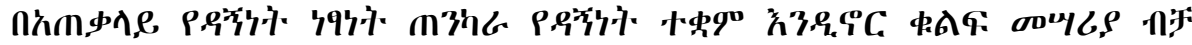

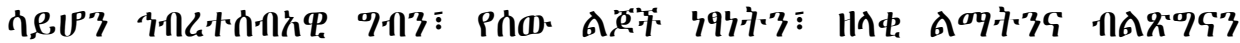

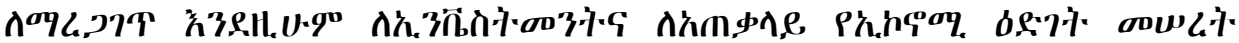

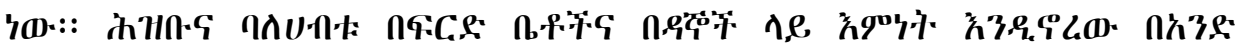

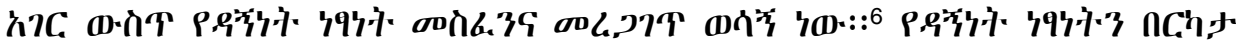

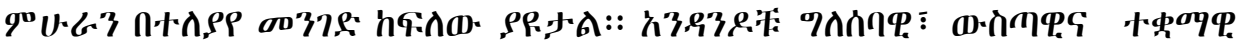
ח

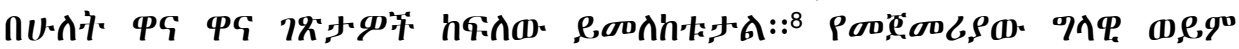

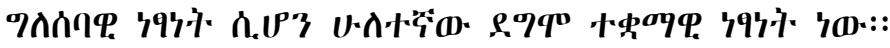

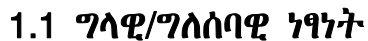

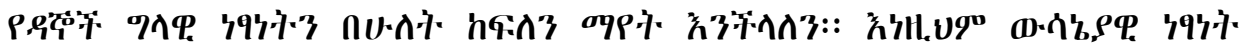

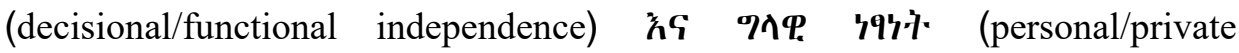

${ }^{4}$ Das, Cyrus and Chandra, K., (Eds.), (2003), Judges and Judicial Accountability, Universal Law Publishing Co. Pvy. Ltd, New Delhi, India, p. 89

${ }^{5}$ Alexander Hamilton, The Federalist No. 78 (cited in Das, Cyrus and Chandra, K., Eds. Id., p. 89),

6 H't. $h^{\text {oqu. }}$

7 Shimon Shetreet, (1994). Justice in Israel: A study of the Israeli Judiciary, Martinus Nijhoff publishers, Boston,

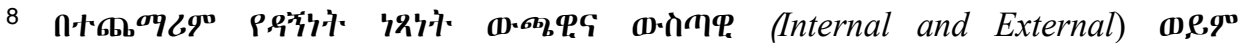

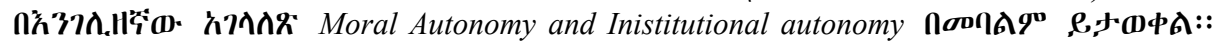

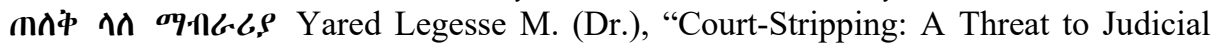
independence", in Gedion Thimothewos and Helen Fikre (Eds), The FDRE Constitution: Some perspectives on the institutional dimension, Ethiopian Constituional Law Series, Vol. VI, College of Law and Goverance, School of Law, AAU, p. 104 , 600 Ant: 


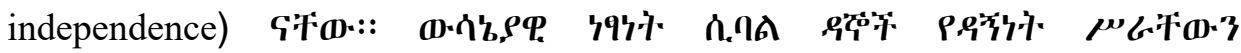

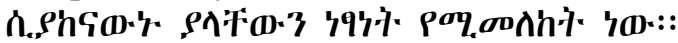

Decisional independence means that in the making of judicial decisions and exercising other official duties, individual judges are subject to no other authority but the law.

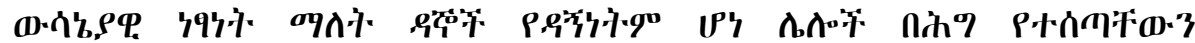

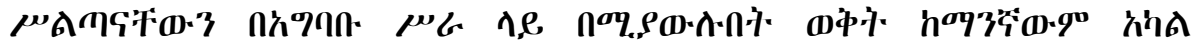

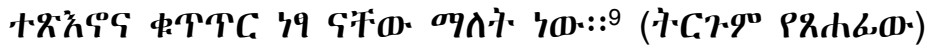

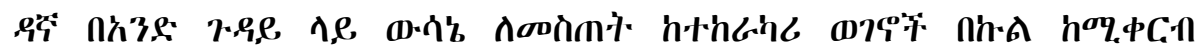

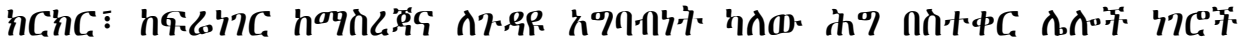

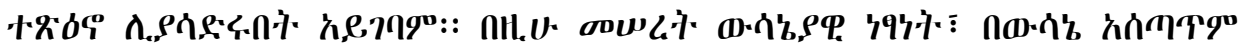

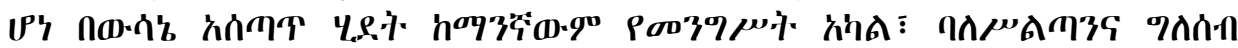

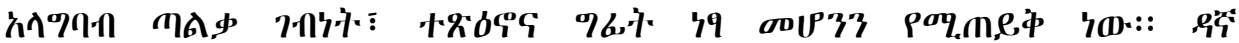

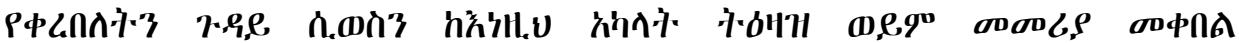

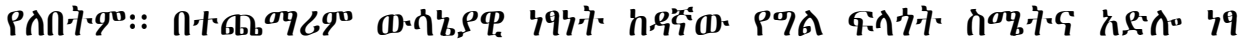

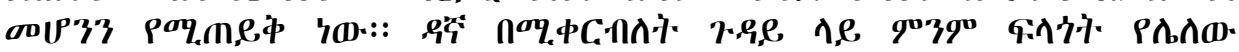

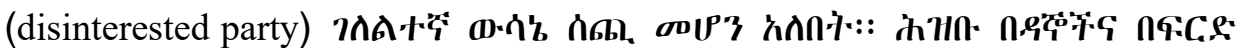

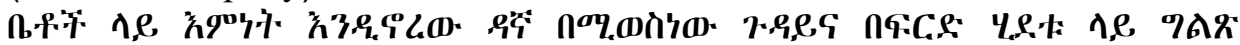

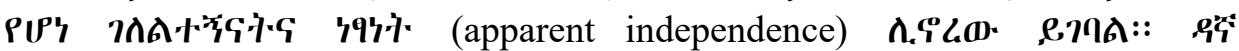

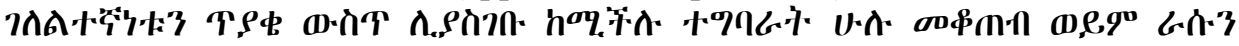

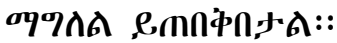

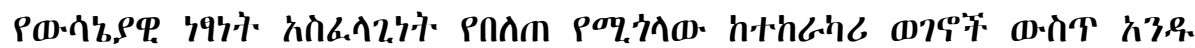

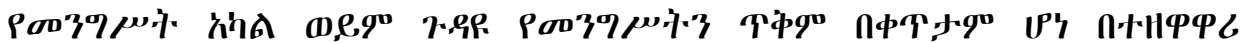

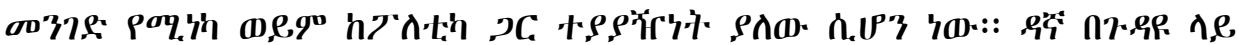

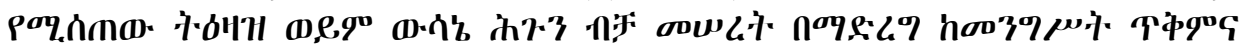

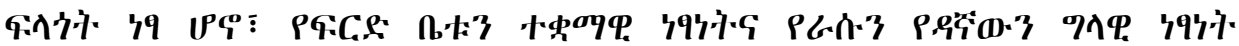
औ3.

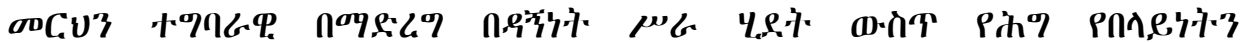

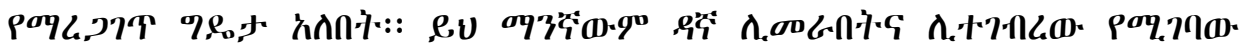

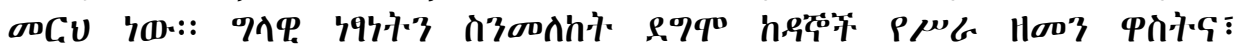
q0A

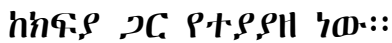

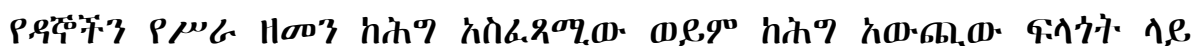

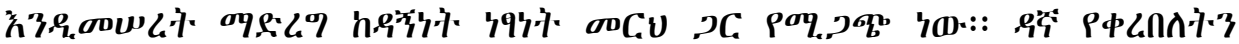

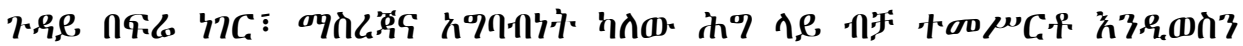

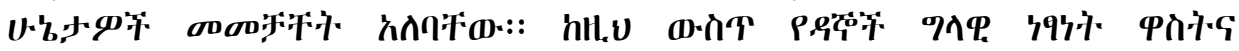

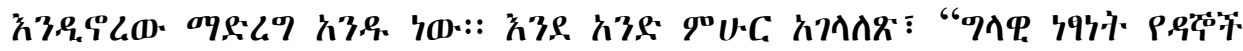

9 T'เ. h⿻و 


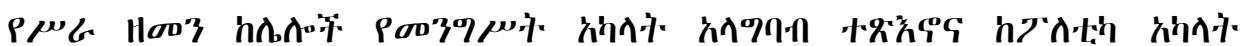

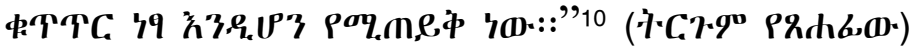

\section{$1.2+\boldsymbol{R}^{\circ 99}$ 1917}

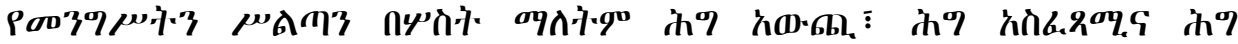

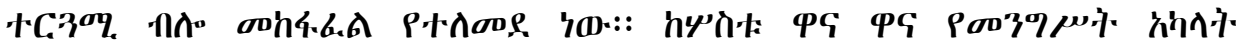

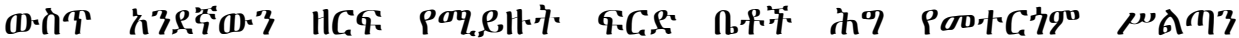

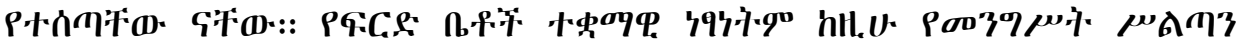

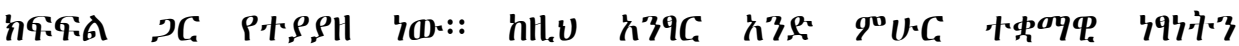

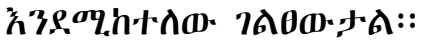

Institutional independence of the judiciary means that the judiciary is not subject to pressure from either the executive or legislature and is not subordinate to either of them particularly in the area of administration of courts.

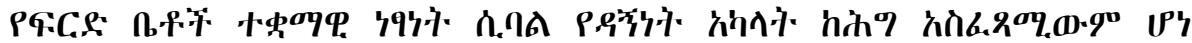

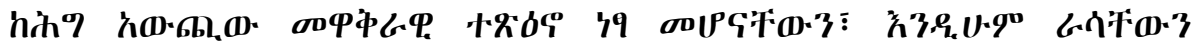

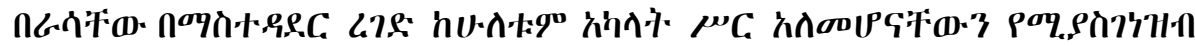
10)::11 ('十C:7.90 P2hbo(D)

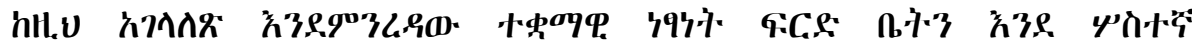

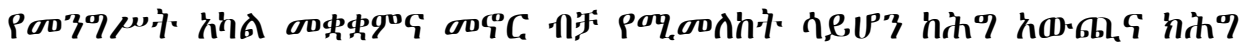

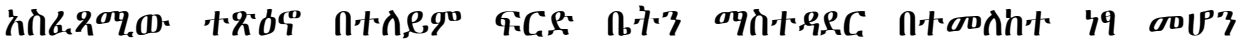

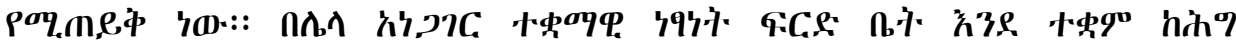

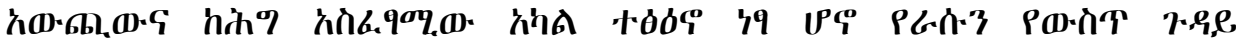

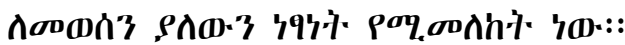

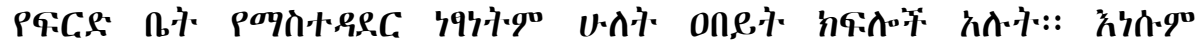

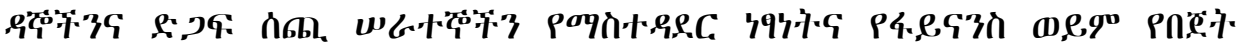

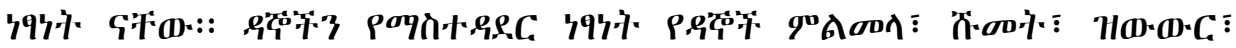

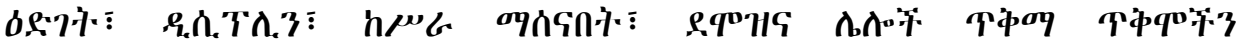

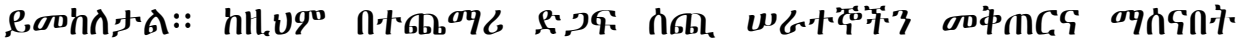

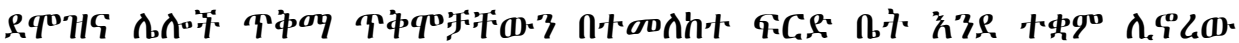

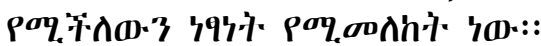

Pद.eg3n o.

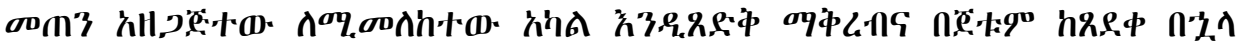

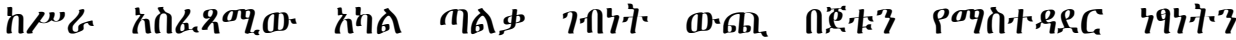

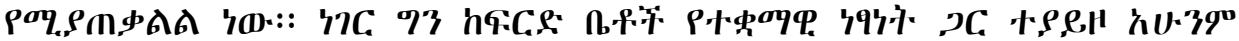

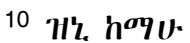

"By personal independence of judges is to mean the enjoyment by individual judges of judicial terms of office and tenure free from the undue or improper influence and control of the political branches".

11 H't hoYu. 


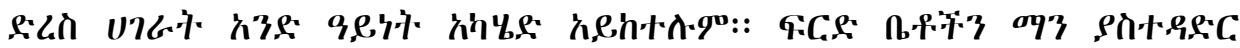
Poq.กक.3

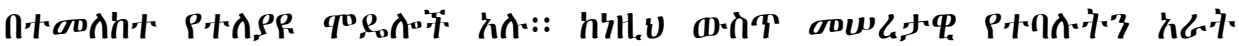
qo.

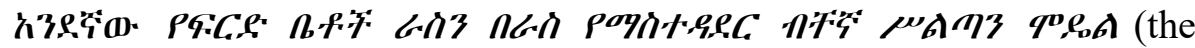

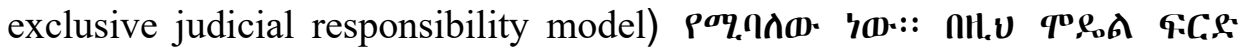

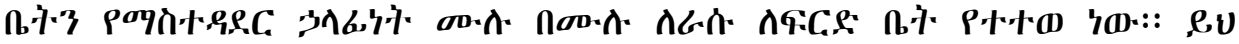
q0,

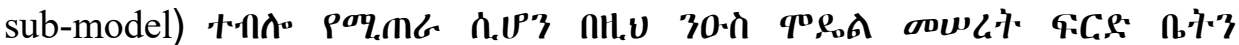

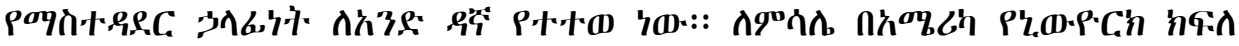

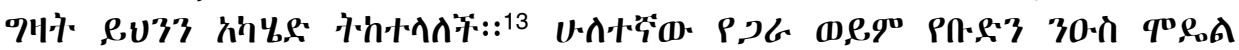

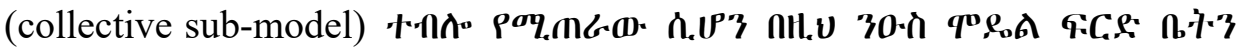

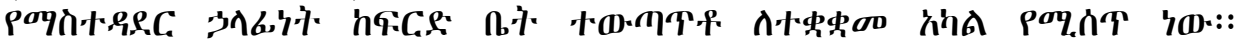

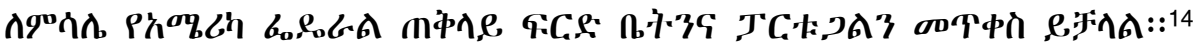

v. त卜 (the exclusive executive responsibility model) poq.nกक. 'וD::

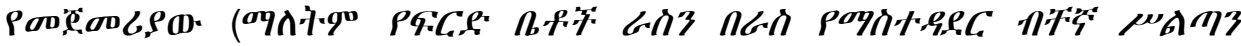

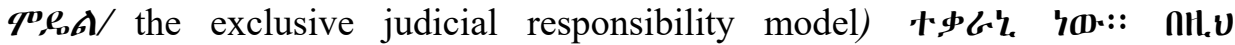

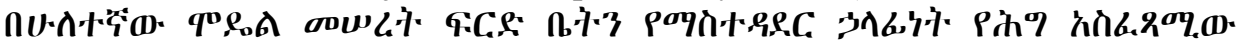

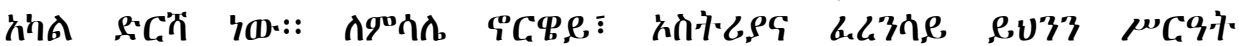

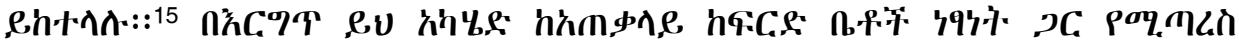
,

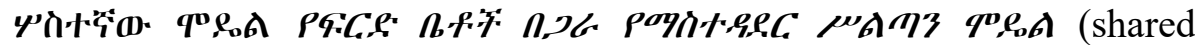
executive-judicial model) poq.9no. ho:: nH,v qo.

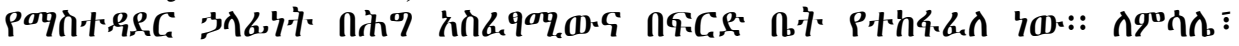

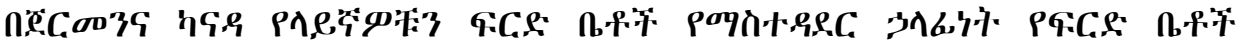

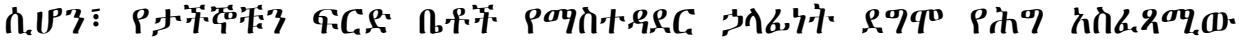

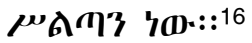

hढ.

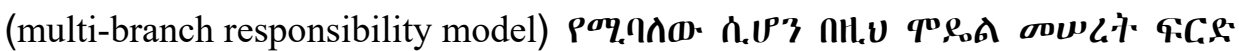

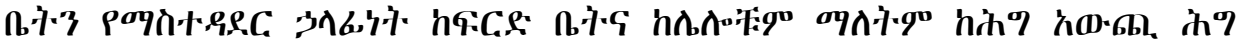

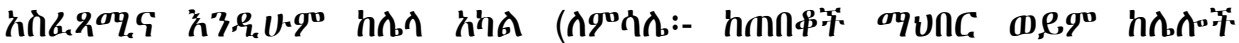

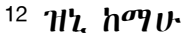

13 Harvey S. (Ed.), (2002). Developing a court leadership and management curriculum, the judicial education reference, information and technical transfer project, (unpublished), p. 55

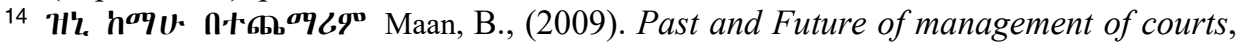
International journal of Court Administration, p. 7 , 6 on hnt::

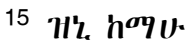

16 H'. $h^{\text {\%qu. }}$
} 


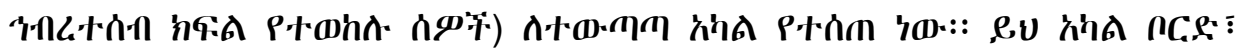

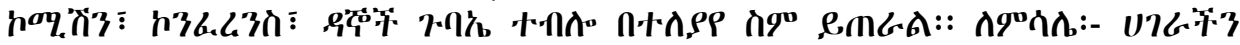

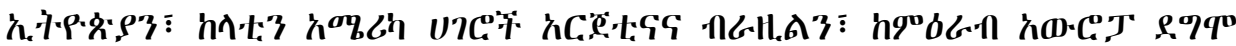

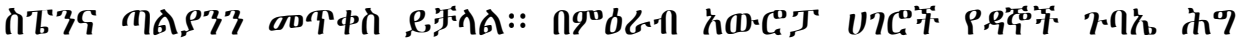

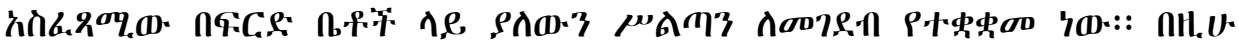

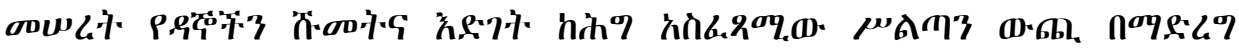
G.

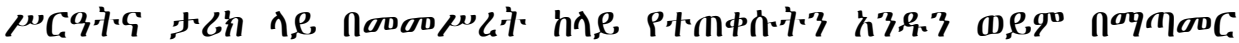
o,eq n Pqo $\ell_{0}$.

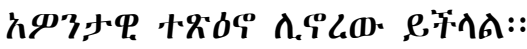

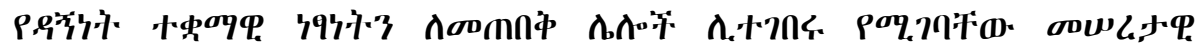

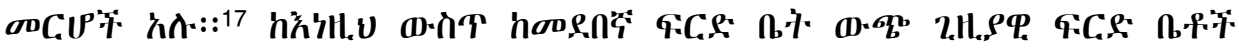

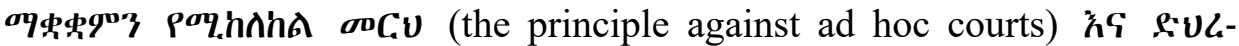

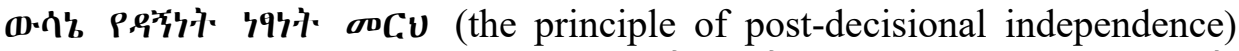

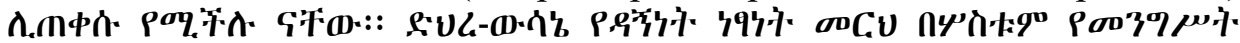

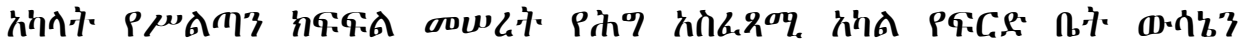

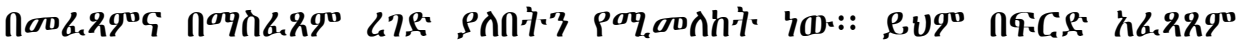

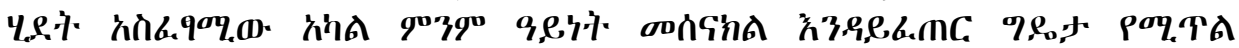

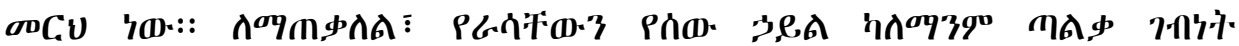

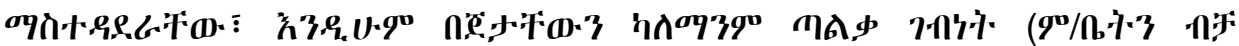

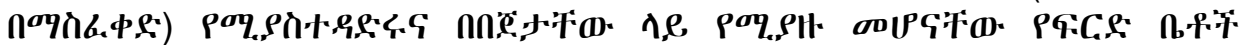

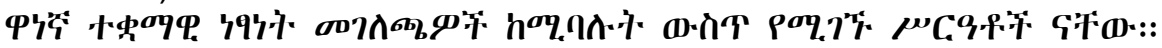

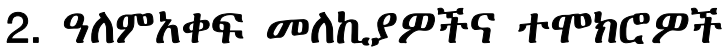

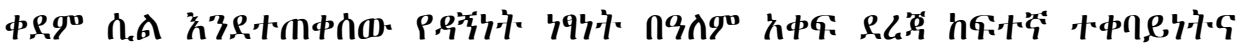

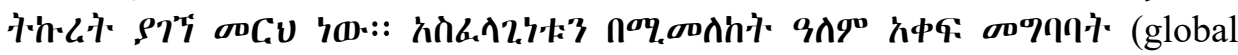

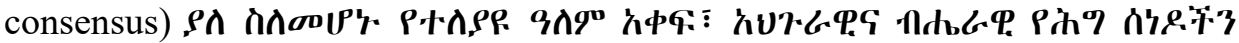

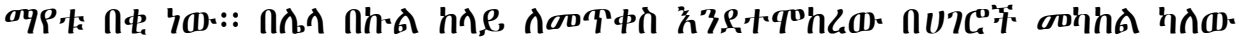

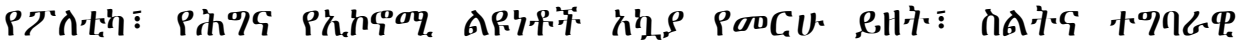

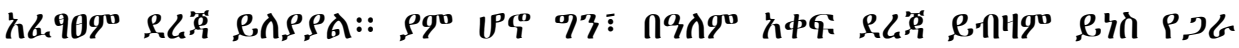

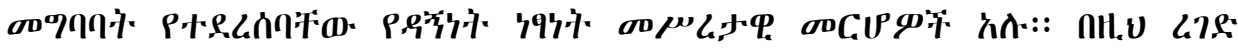

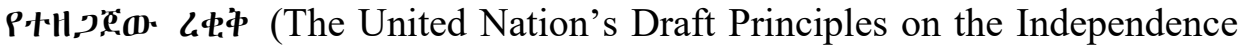

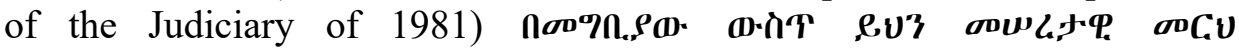

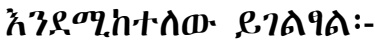

17 Alemayehu Tegene (2007), Independence and Accountability of Oromia Regional State Judiciary in light of the Judicial Reform Program, (Unpublished), LLM Thesis, AAU, Faculty of Law, p. 16 


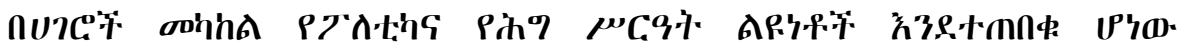
तก

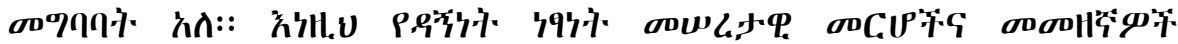

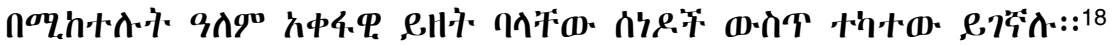

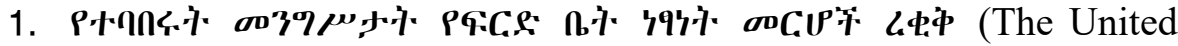
Nations Draft Principles on the Independence of the Judiciary, 1981)

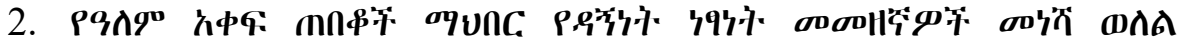
(The International Bar Association and Minimum Standard of judicial Independence 1982 /New Delhi Standards)

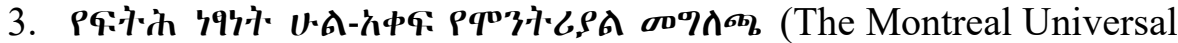
Declaration on the Independence of Justice of 1983 /Universal Declaration)

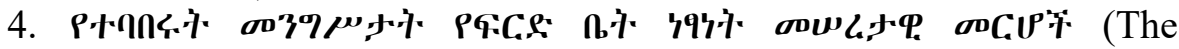
United Nations Basic Principles on the Independence of the Judiciary of 1985)

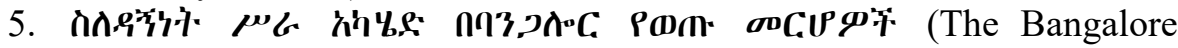
Principles of Judicial Conduct of 2002)

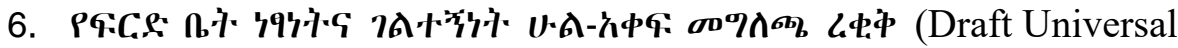
Declaration on the Independence and Impartiality of the Judiciary of 1989) $)^{19}$

18 USAID, (2009), Guide to Court Reform and the role of Court Personel, (Unpublished), p. 17

"Notwithstanding the diversities of political system and legal mechanism in different countries there is a basic and substantial consensus on the principles and minimum standards relating to the independence of justice in the constitutions and legal systems of world."

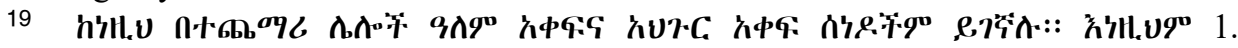
Draft Principles on the Independence of the Judiciary ("Siracusa Principles"), prepared by a committee of experts convened by the International Association of Penal Law, the International Commission of Jurists, and the Centre for the

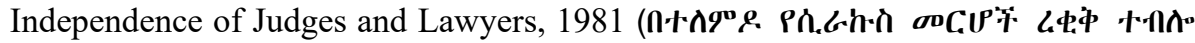
Poq.m6.(D) $\doteqdot$ 2. Minimum Standards of Judicial Independence adopted by the International Bar Association, 1982. 3. Draft Universal Declaration on the Independence of Justice ("Singhvi Declaration") United Nations Special Rapporteur on the Study on the Independence of the Judiciary, 1989. 4. The Beijing Statement of Principles of the Independence of the Judiciary in the Lawasia Region, adopted by the 6th Conference of Chief Justices, August 1997. 5. The Latimer House Guidelines for the Commonwealth on good practice governing relations between the Executive, Parliament and the Judiciary in the promotion of good governance, the rule of law and human rights to ensure the effective implementation of the Harare Principles, 


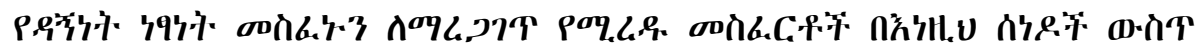

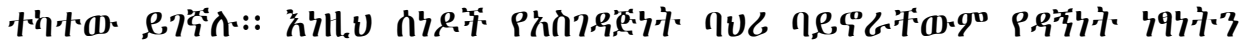

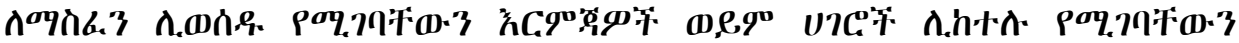

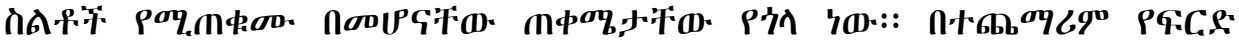

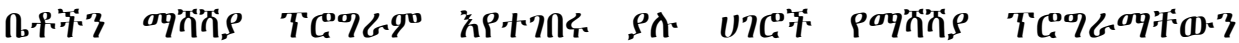

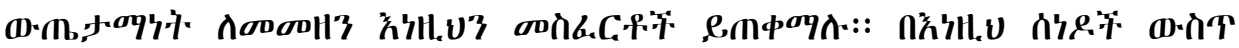

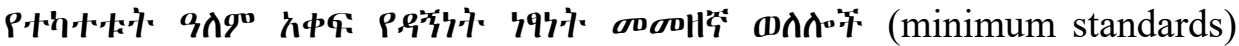

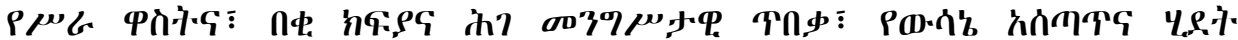

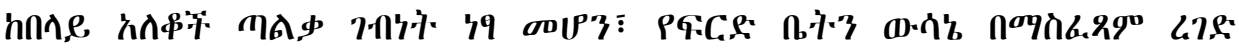

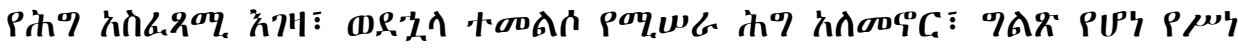

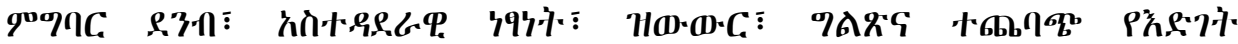

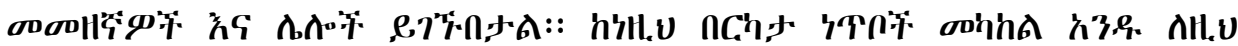

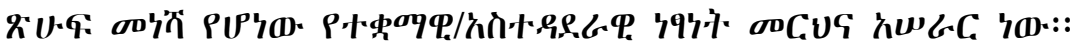

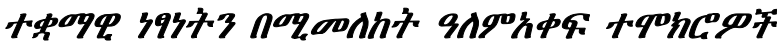

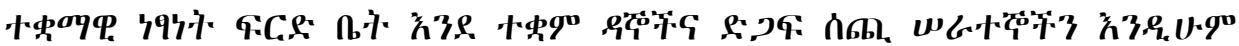

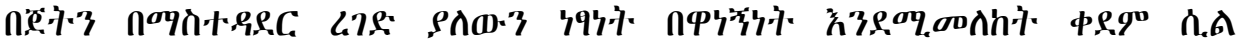

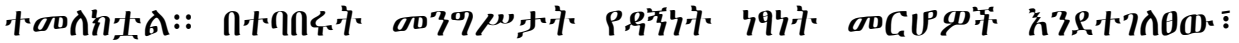

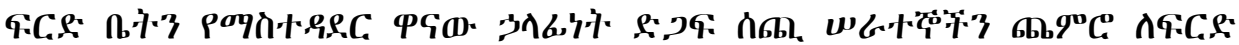

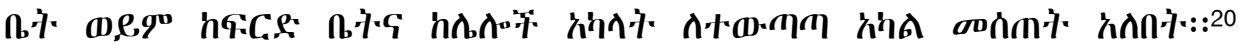

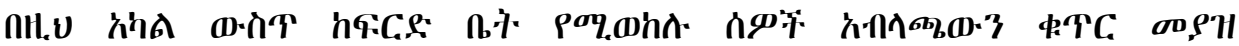

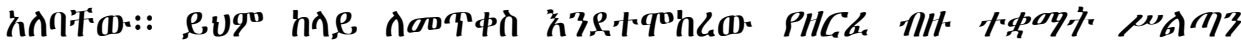

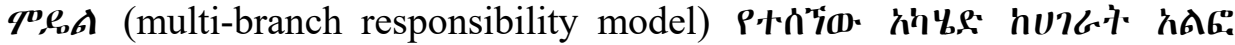

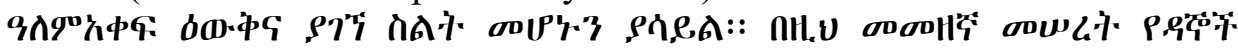

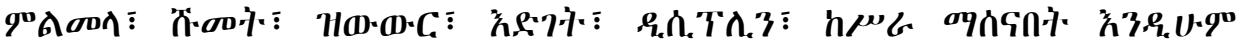

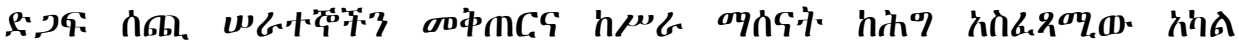

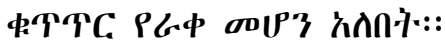

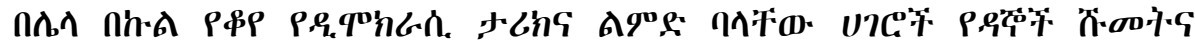

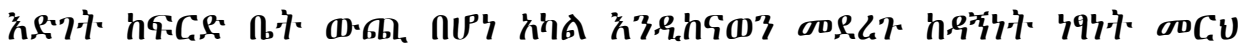

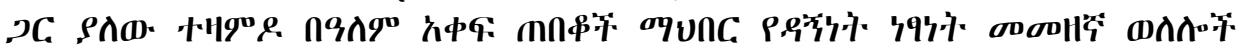

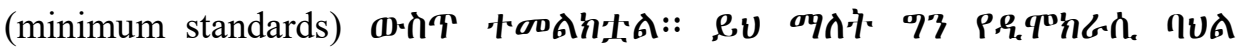

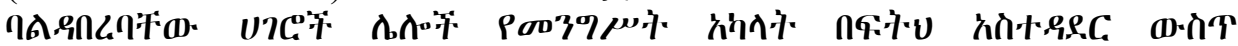

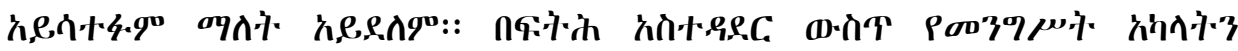

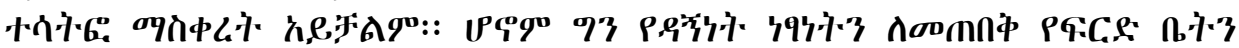

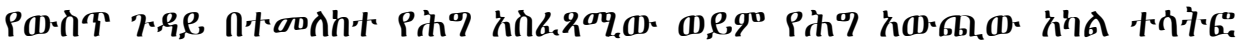

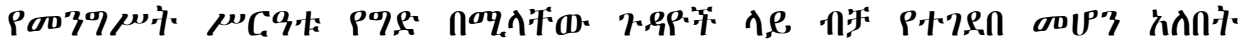

1998. (Commentary on The Banglore Principles of Judicial Conduct, UN Office of Drug and Crime, September 2002, p. 12 ,

20 International Commission of Jurists (2007). International Principles on the Independence and Accountability of Judges, Lawyers and Prosecutors (Practioners Guide No. 1), Geneva, Switherland, p. 21 


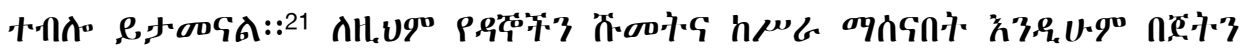

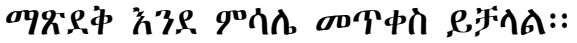

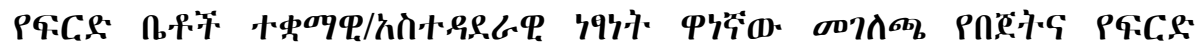

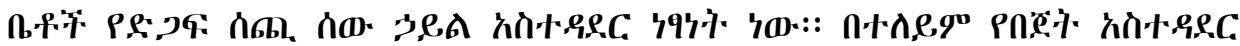

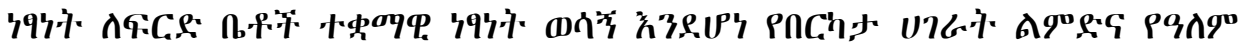

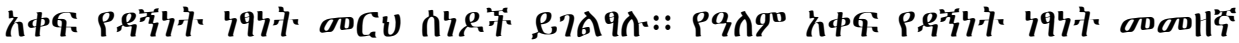

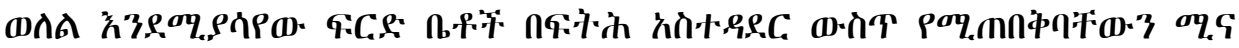

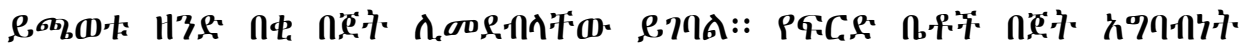

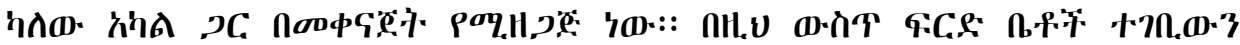

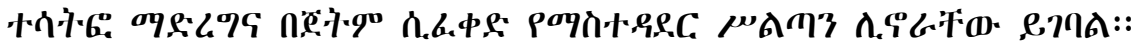

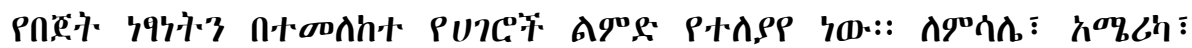

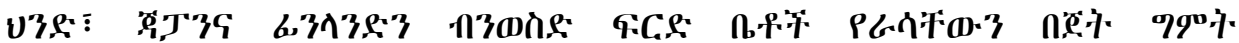

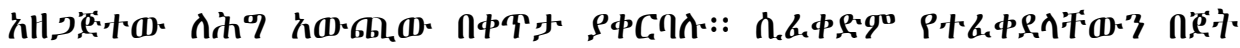

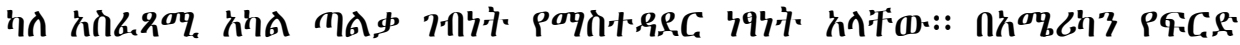

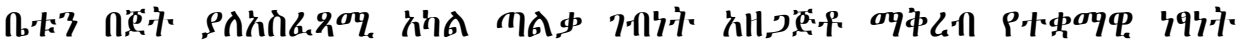

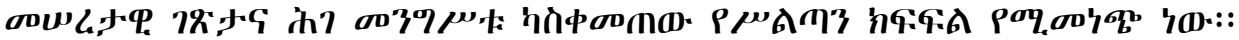

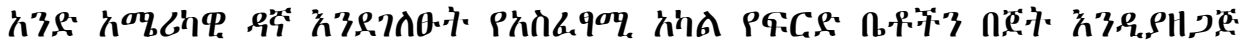

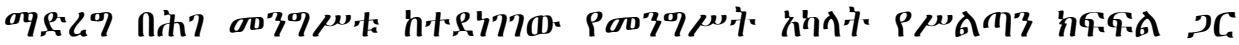
Poq.Jg ho:::22

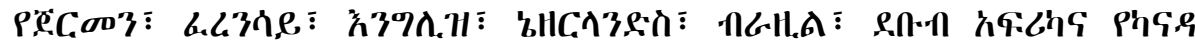

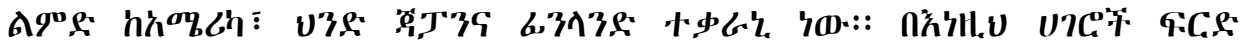

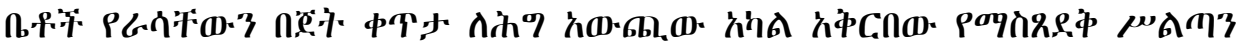

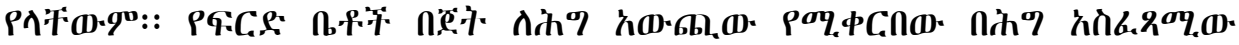

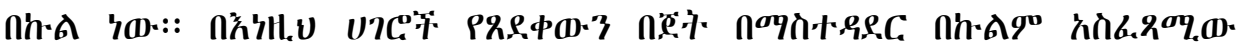

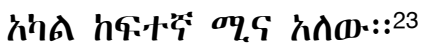

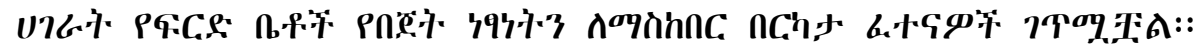

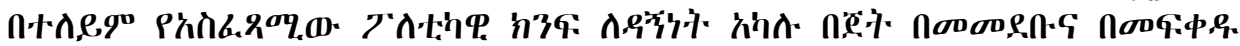

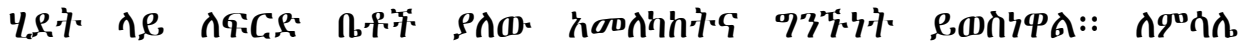

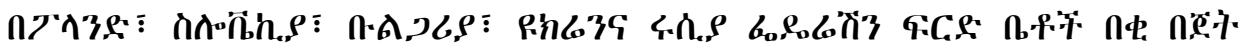

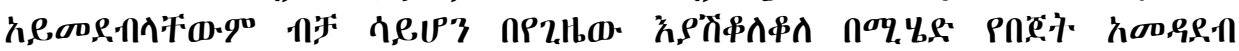

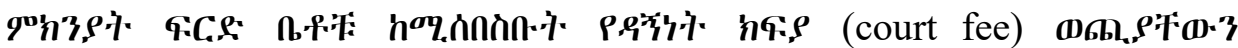

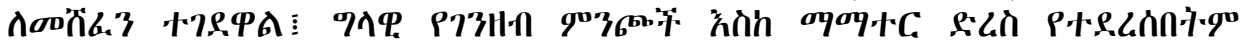

${ }^{21}$ Rekosh, Edwin, (2002). Emrging lessons from reform efforts in Eastern Europe and Eurasia, p. 53 and p. 72 in Office of Democracy and Governance, Giudance for promoting Judicial Independence and Impartiality, Technical publication series, Washington, USA

22 "... It is in conflict with the division of power which the constitution contemplates to allow the executive department to formulate the budget for the judiciary".

Sarviilina, S., (2010), Court Administration in Finland, Stocholm Institute for Scandinevian Law, (unpublished), p. 596

${ }^{23}$ Rekosh, Edwin, supra note 21., p. 74 


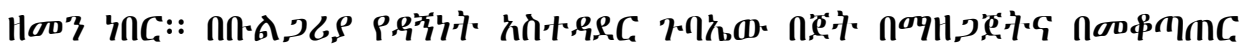
Lis:

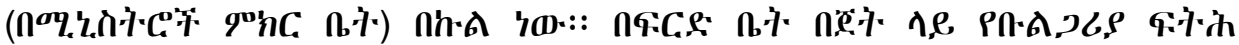

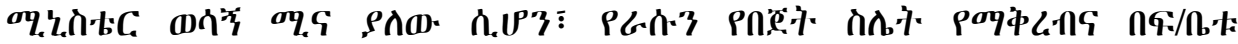

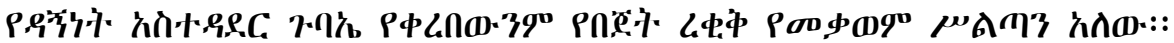

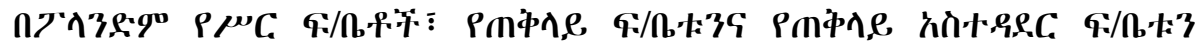

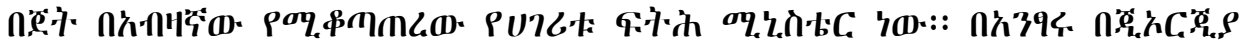

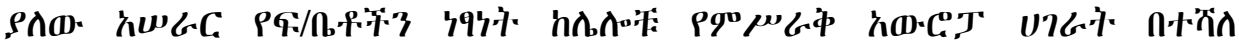

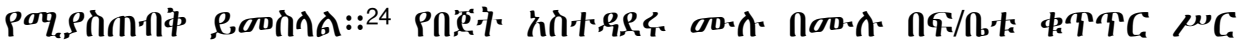

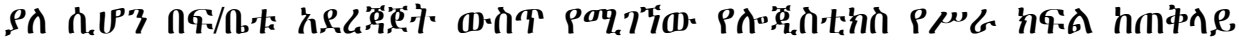

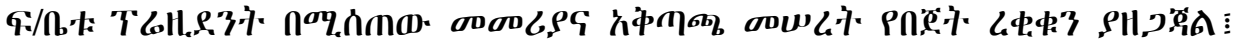

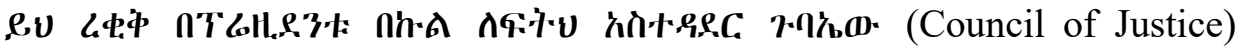

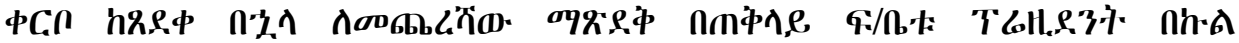

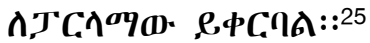

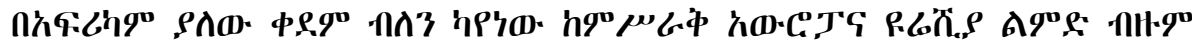
h, לn,

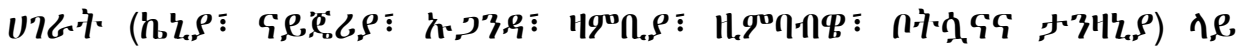

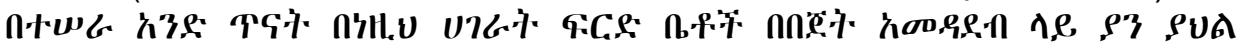

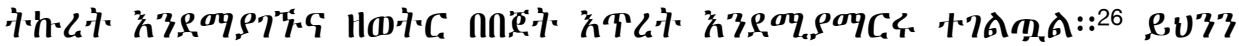

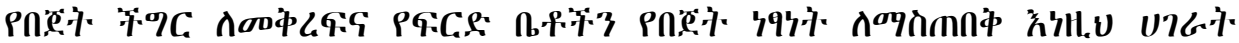

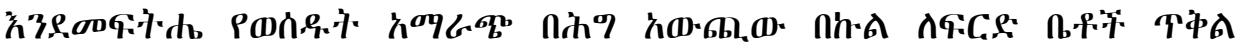

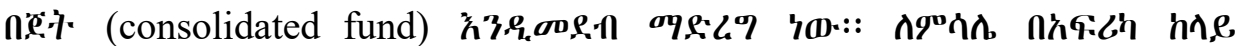

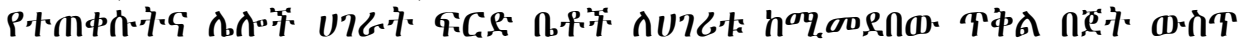

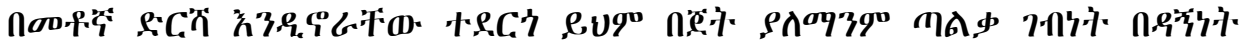

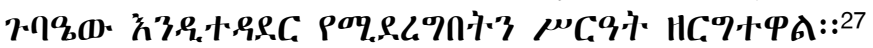

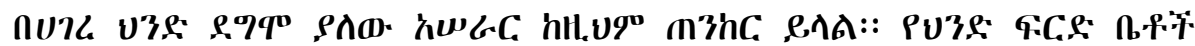

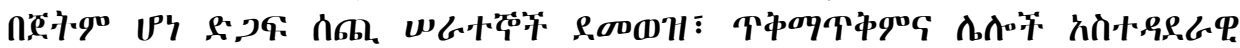

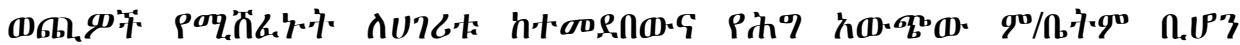

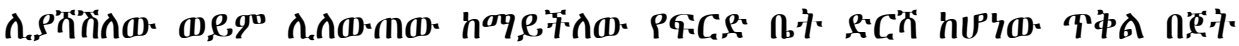

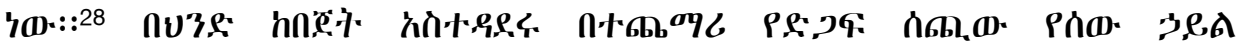

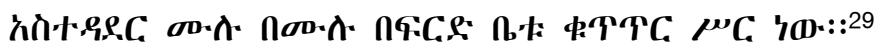

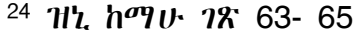

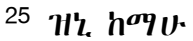

26 Widner, Jennifer, (January 2002). "Judicial Independence in Common Law Africa", in Office of Democracy and Governance, Giudance for promoting Judicial Independence and Impartiality, Technical publication series, Washington, USA, 1\% 48

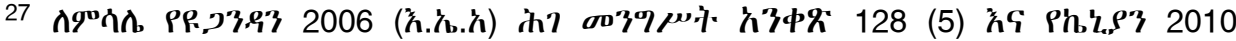

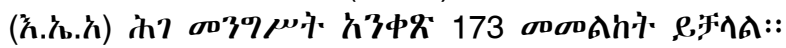

28 M.P. Singh (2000). Securing the Independence of the Judiciary-The Indian Experience, Indian International \& Comparative Law Review, Vol 10 No. 2, 1\% 253 29 H'. $h^{\text {oqu }}$.
} 


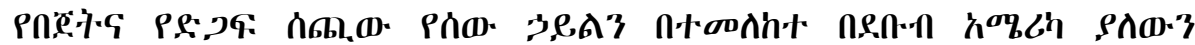

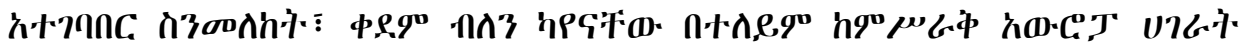

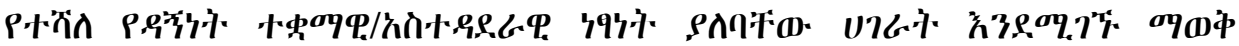

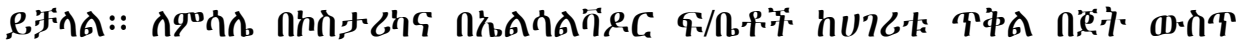

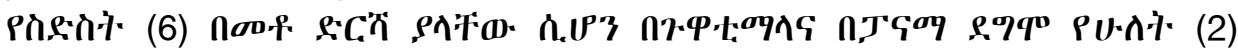

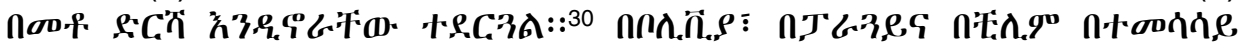

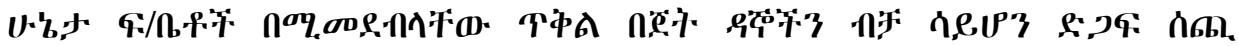

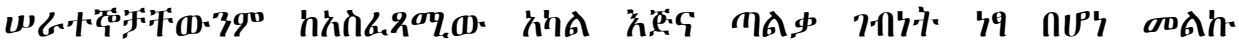

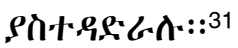

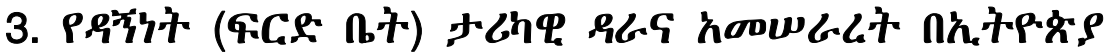

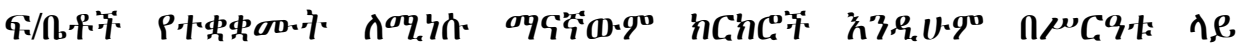

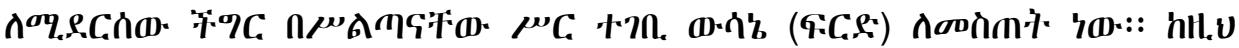

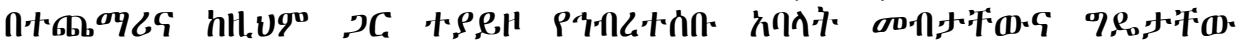
ह3.9.hतC

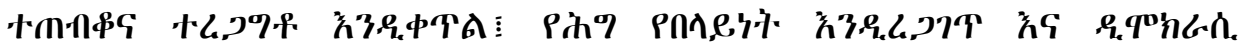

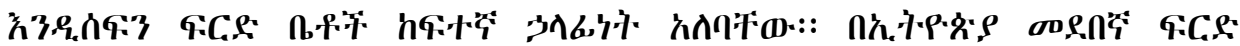

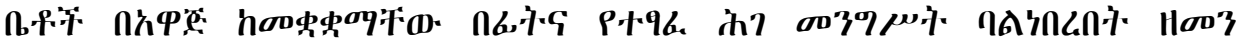

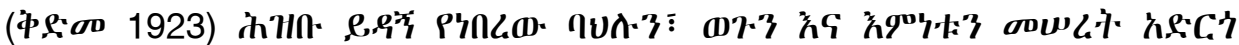

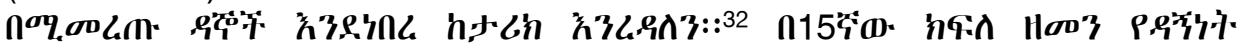

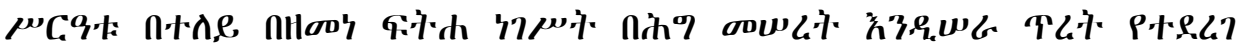

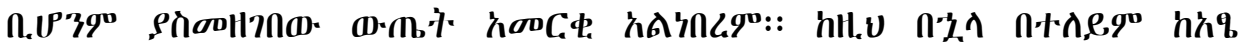

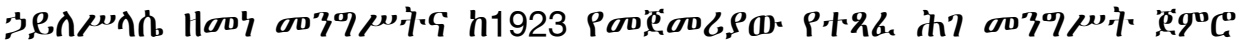

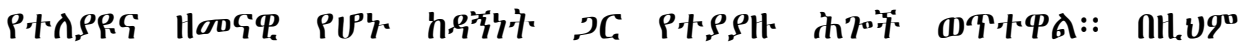
oDULi:-

30 Margaret Popkin (January 2002). Efforts to inhance Judicial independence in Latin America: A Comparative perspective, in Office of Democracy and Governance, Giudance for promoting Judicial Independence and Impartiality, Technical publication series, Washington, USA, 7\% 122

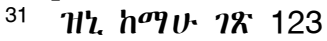

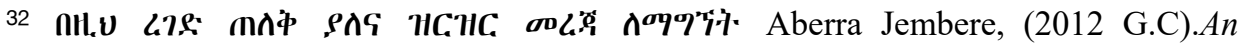
Introduction to the Legal History of Ethiopia (1434-1974), Some Aspects of substantive and procedural laws, Shama Books and Master Printing Press plc, Addis

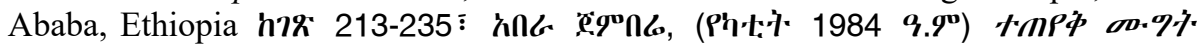

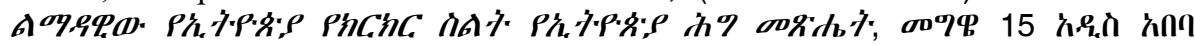

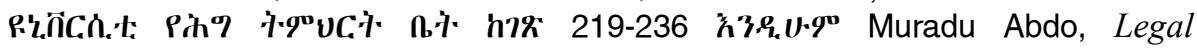
History and Tradition, (Unpublished material) Addis Ababa University, Faculty of Law, p. 256-267 , eos 
v) $019349.9^{\circ}$ P.g.

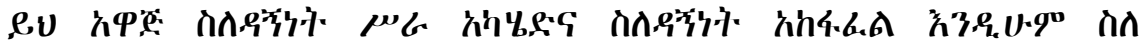

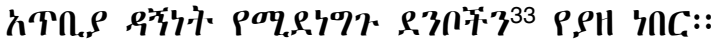

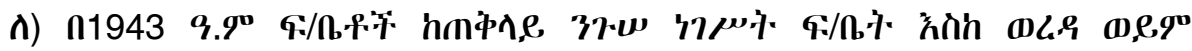

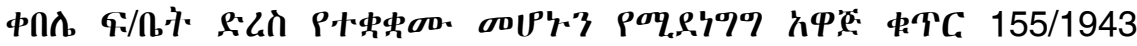
(DT:1::

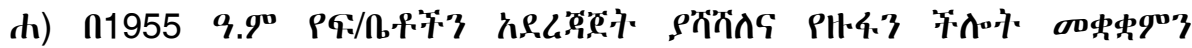

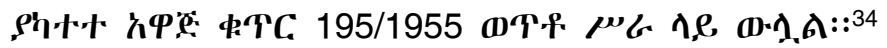

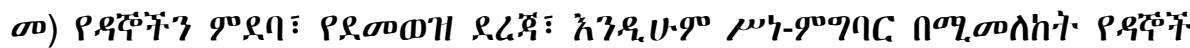

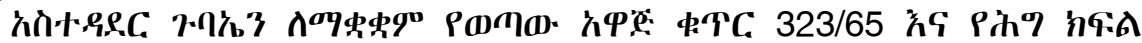

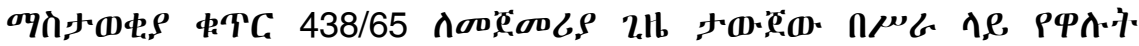
01965 9.90 h0:::35

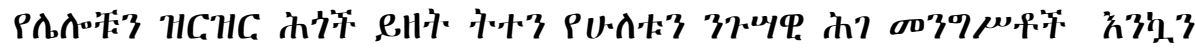

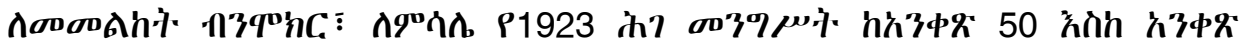

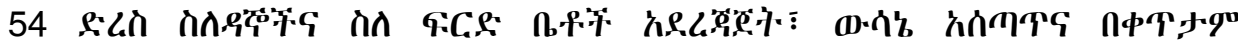

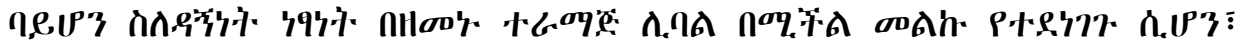

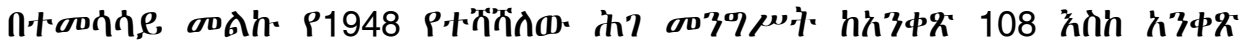

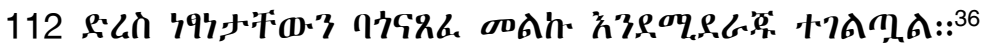

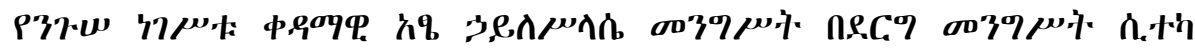

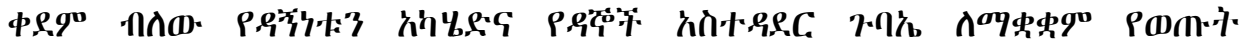

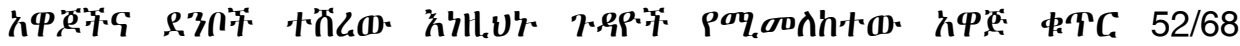

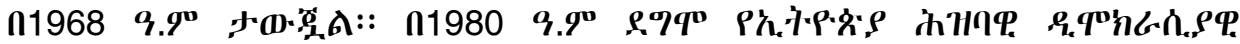

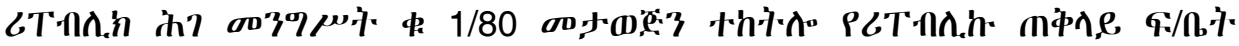

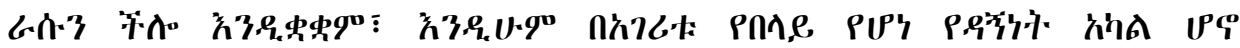

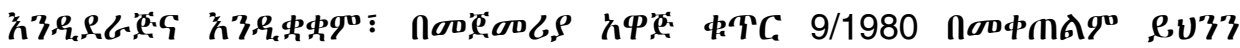

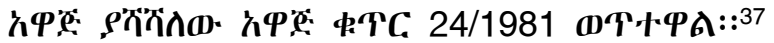

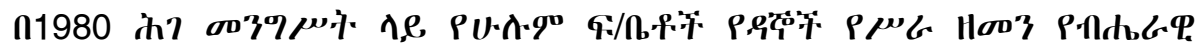

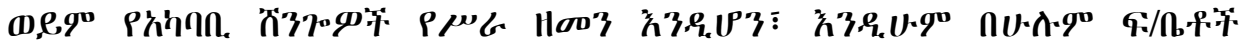

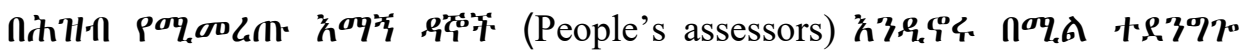

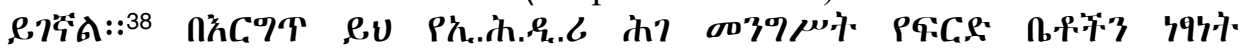

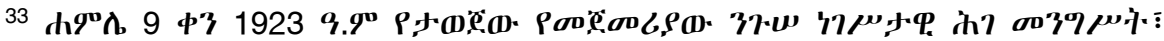

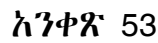

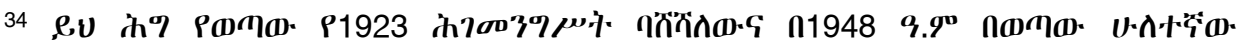

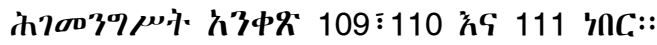

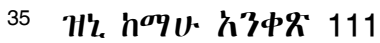

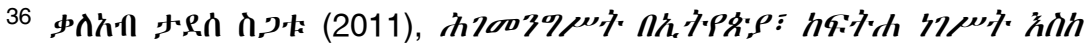

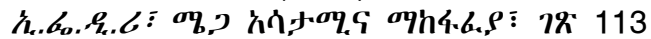

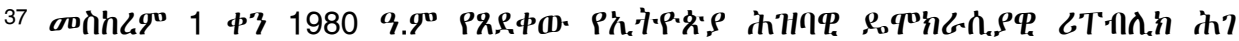

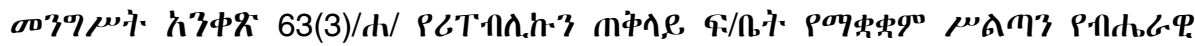

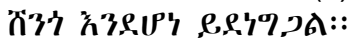

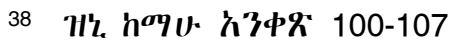




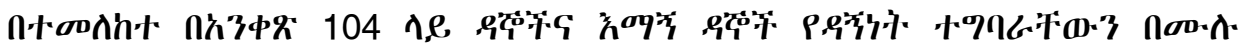

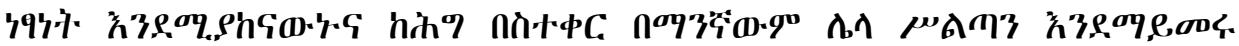

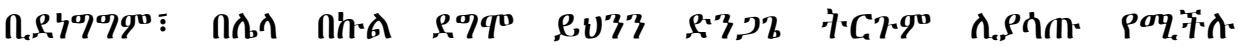

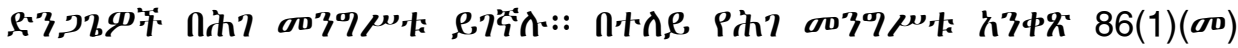

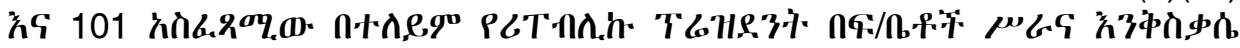

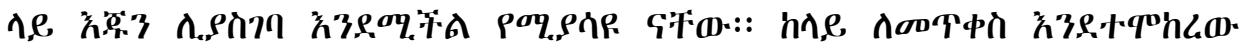

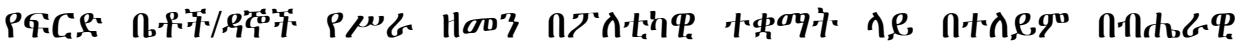

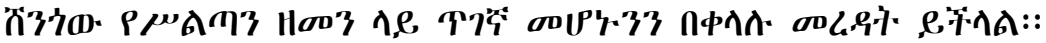

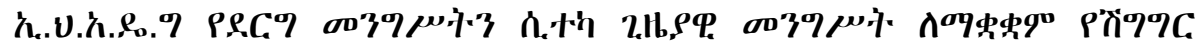

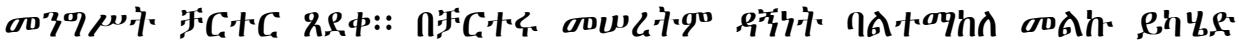

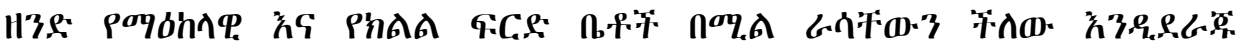
+PC.'

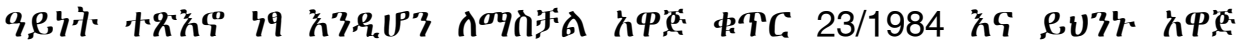

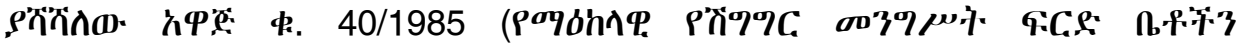

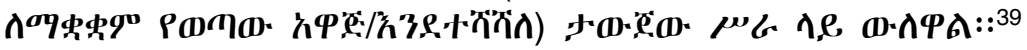

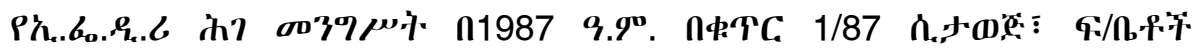

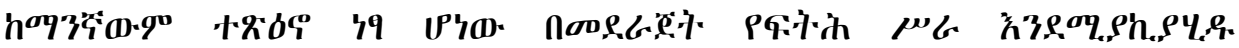

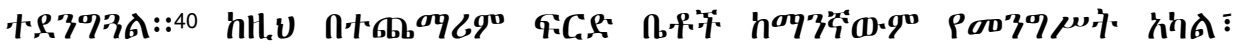

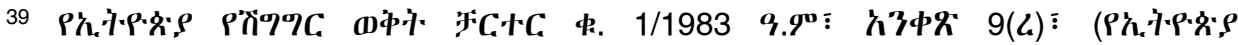

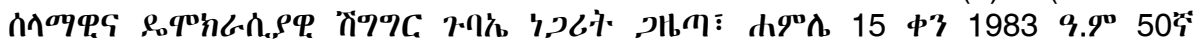
900 \% $\$ .1$

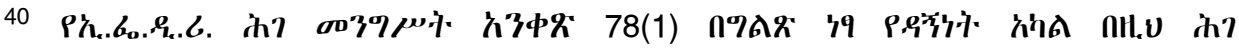

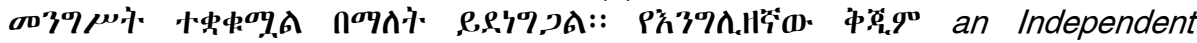

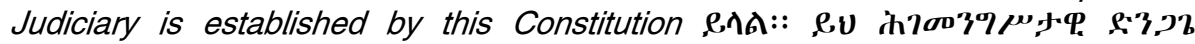

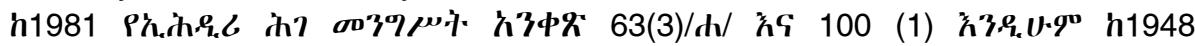

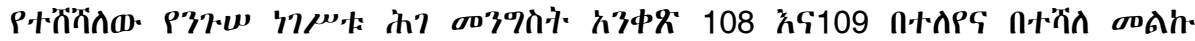

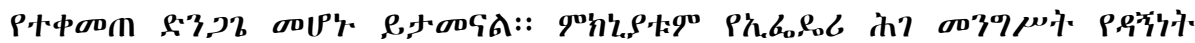

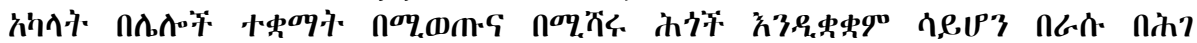

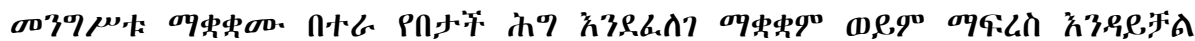

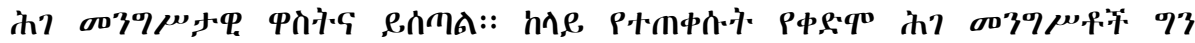

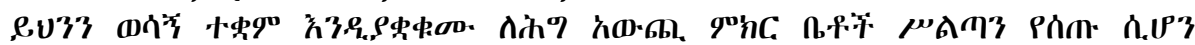

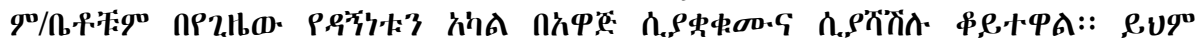

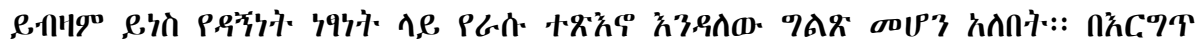

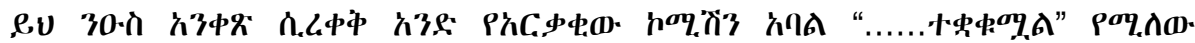

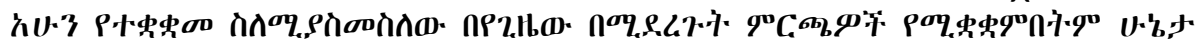

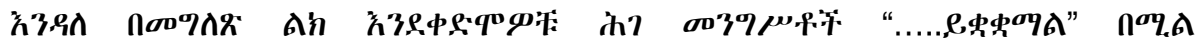

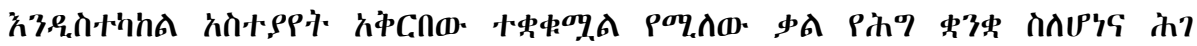

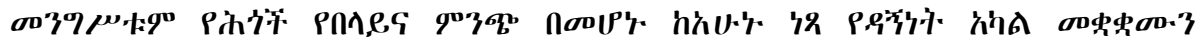

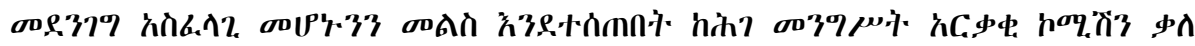

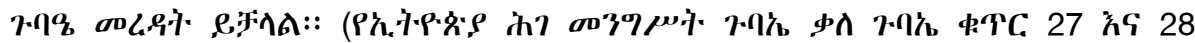

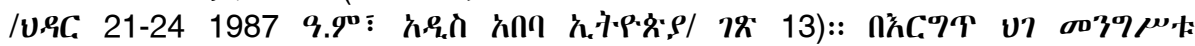

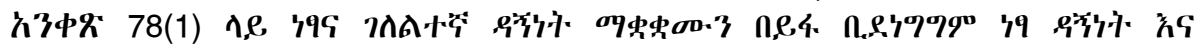

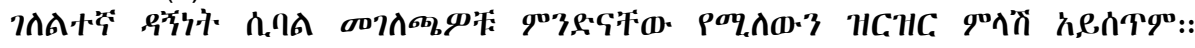




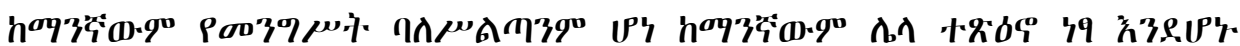

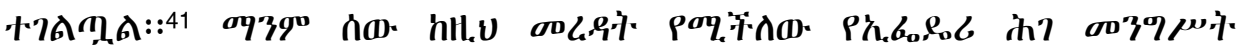

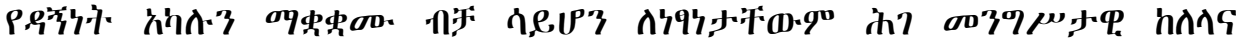

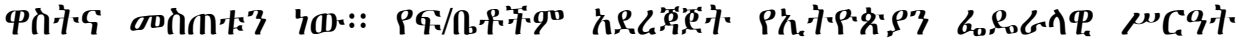

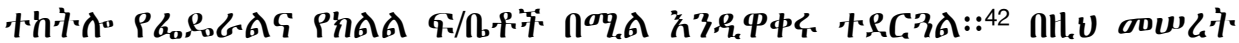

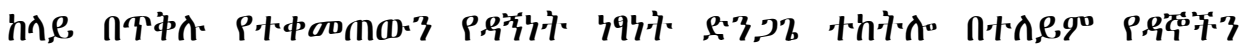

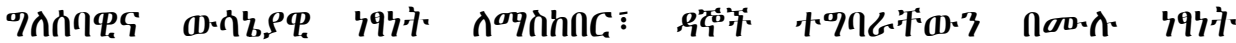

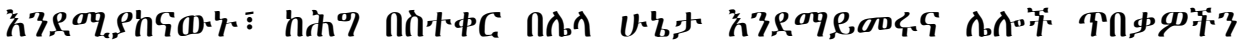

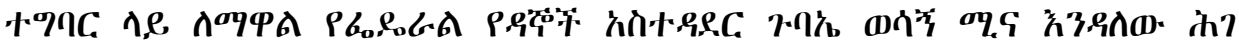

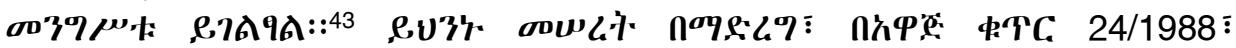

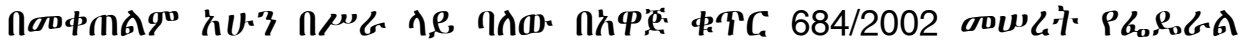

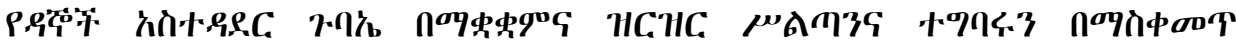

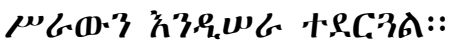

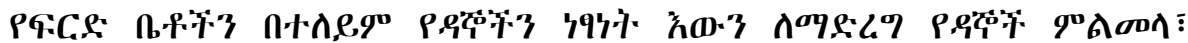

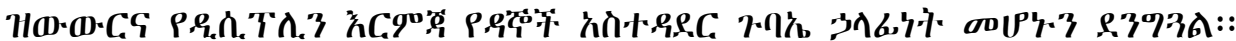

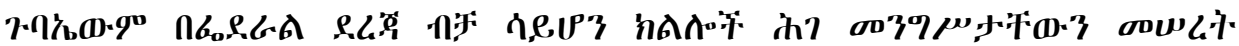

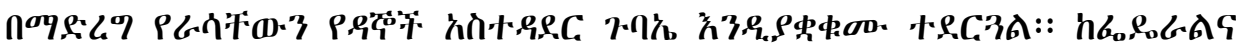

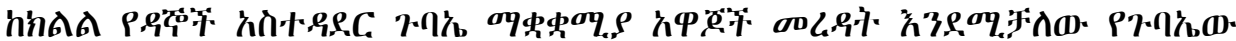

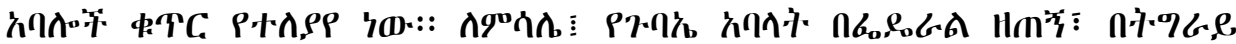

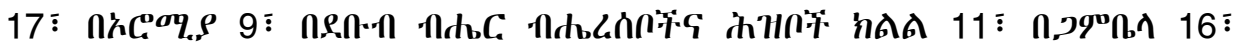

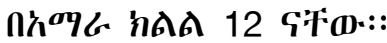

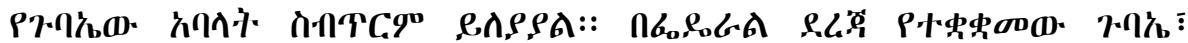

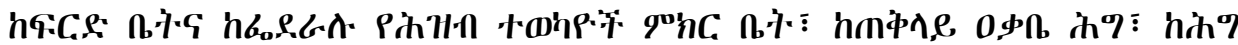

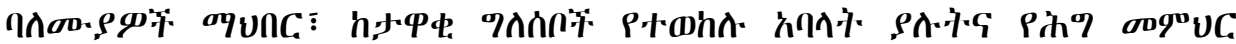

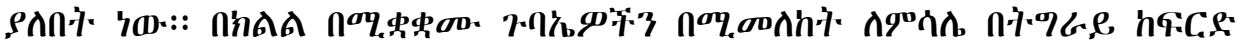

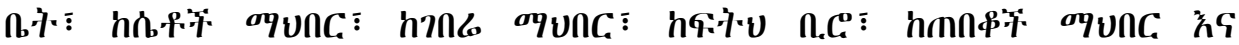

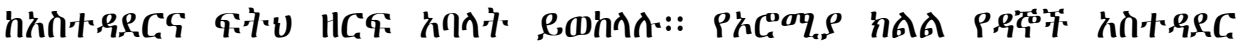

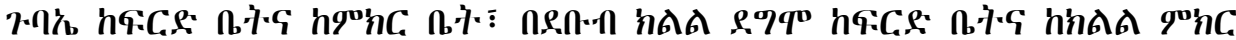

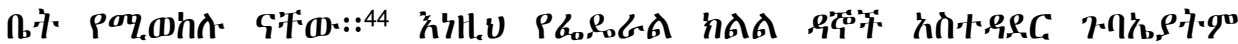

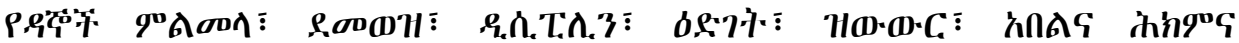

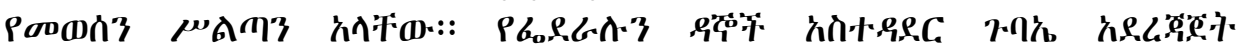

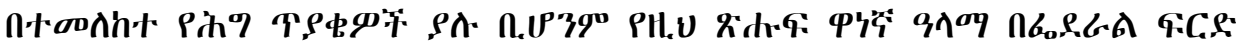

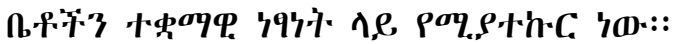

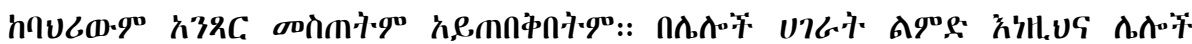

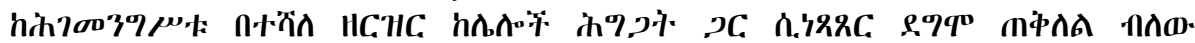

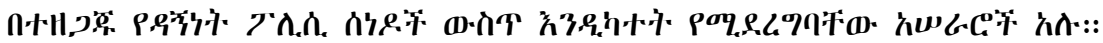

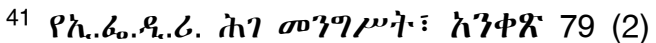

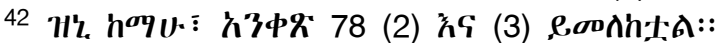

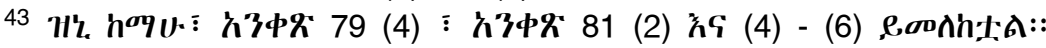

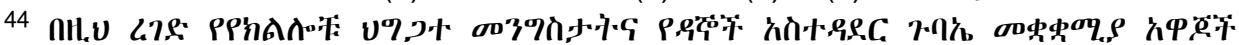

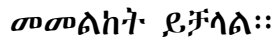




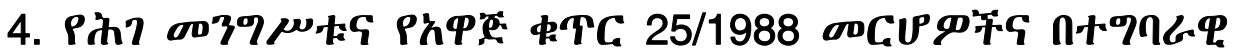

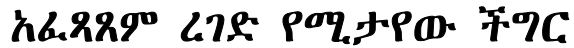

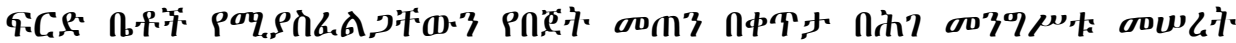

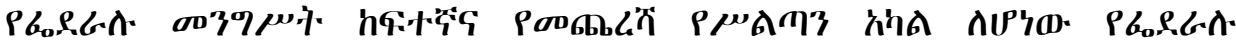

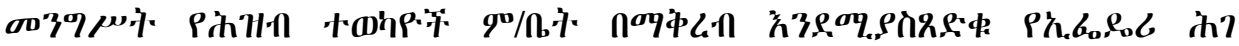

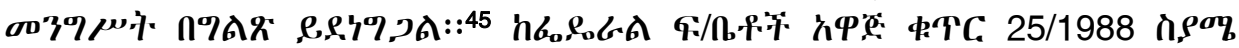

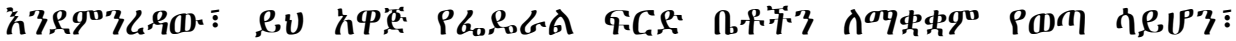

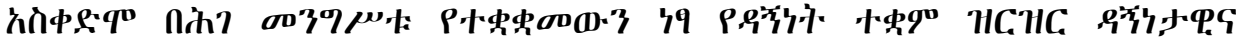

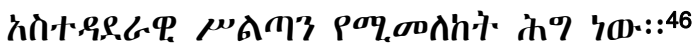

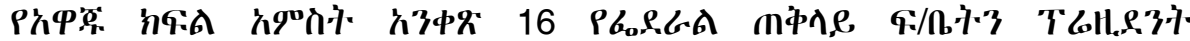

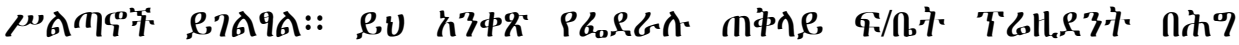

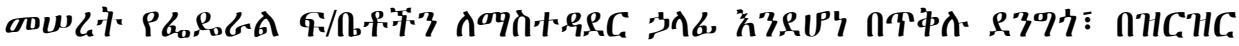

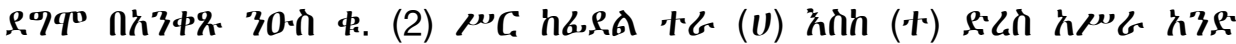

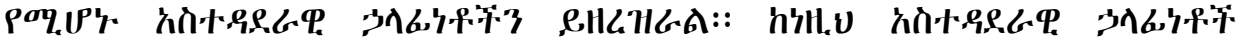

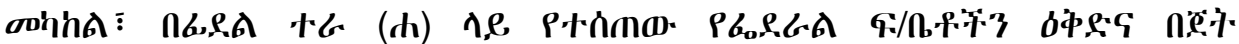

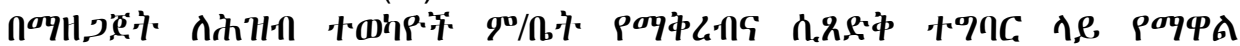

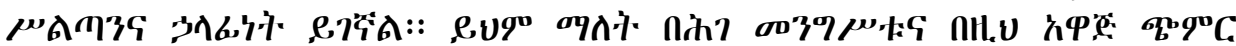
oqद्Fo.9

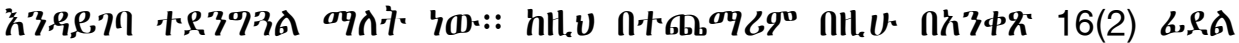

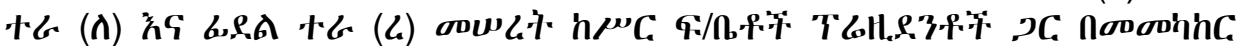
h.9\% क.

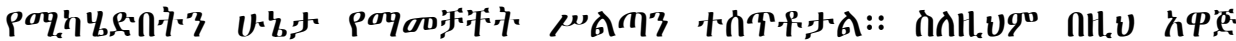

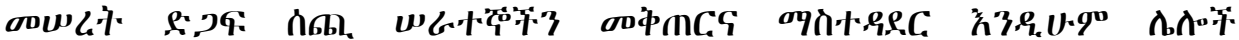

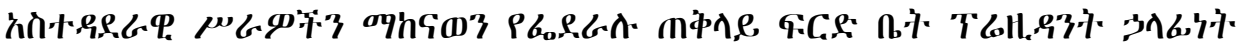

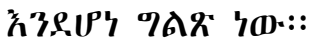

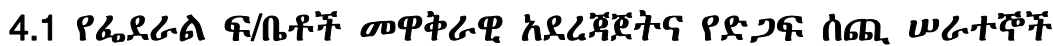

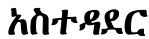

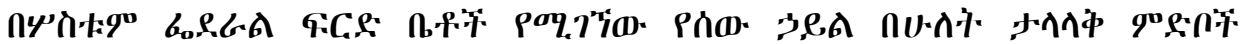

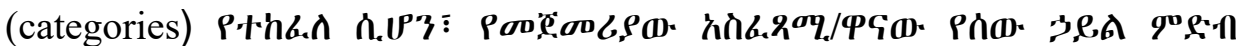

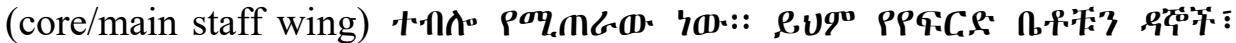

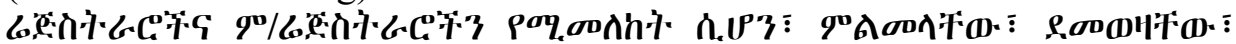

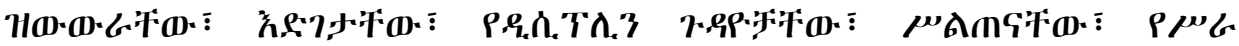

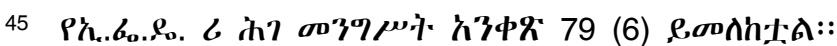

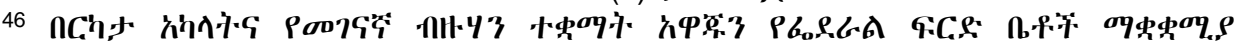
久

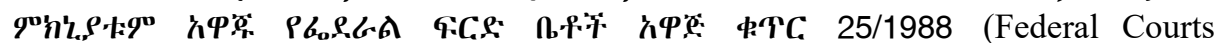

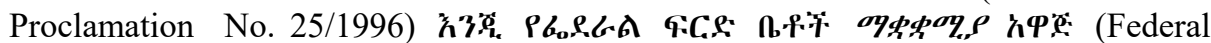

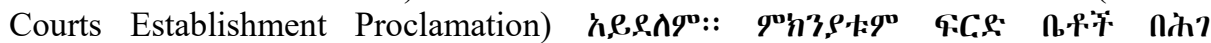

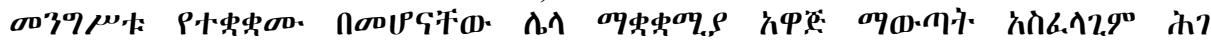

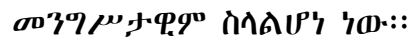




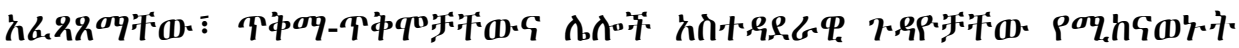

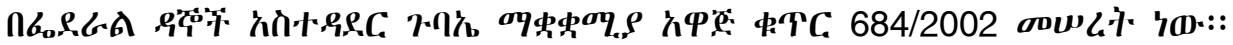

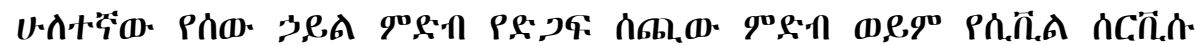

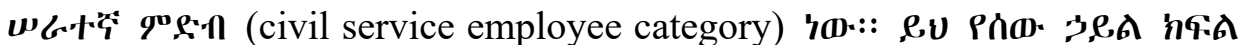

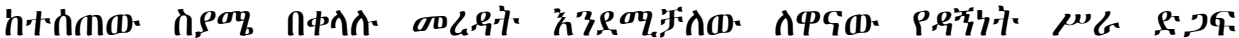

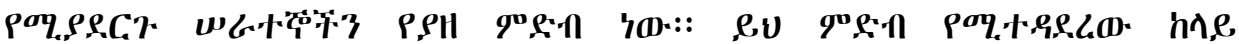

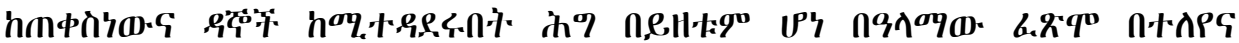

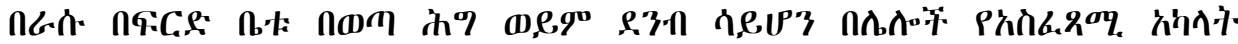

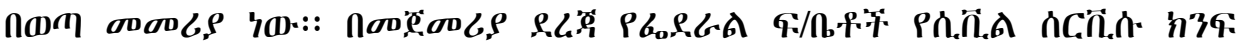

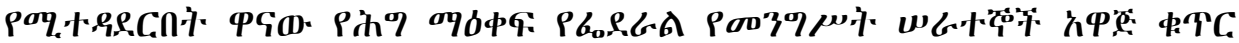

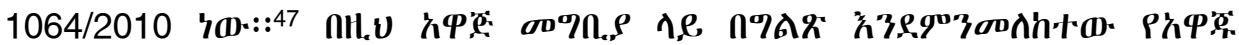

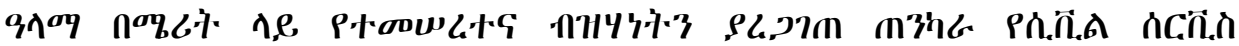

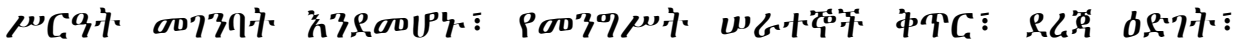
Ho.d.C

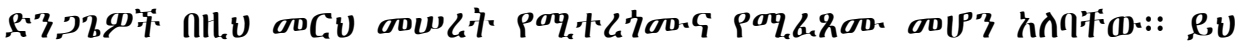

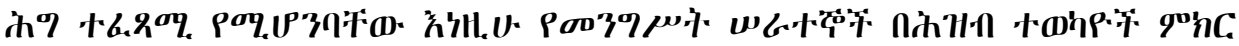

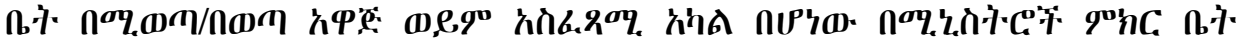

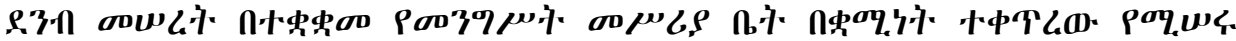

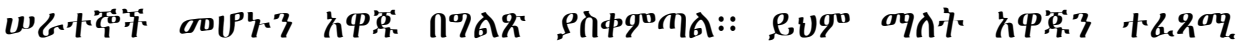

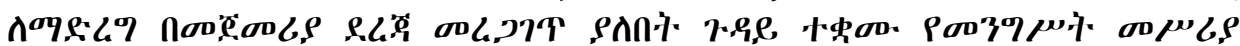

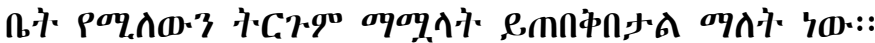

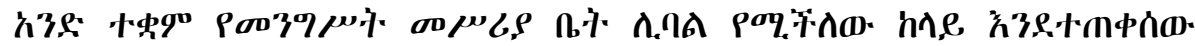

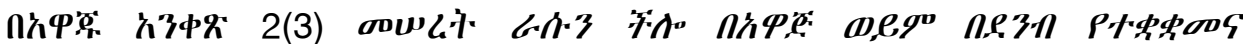

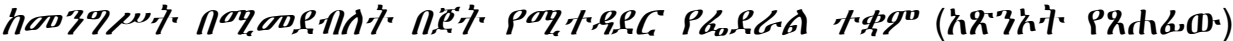

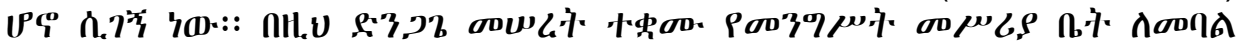

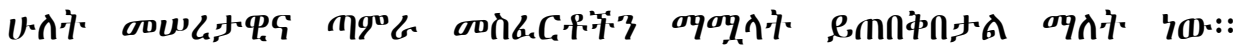

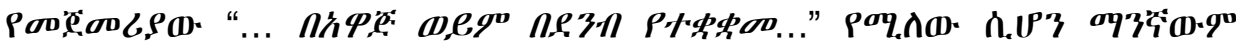

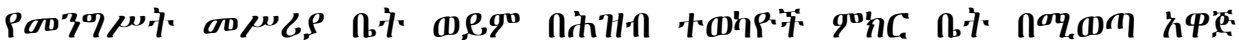

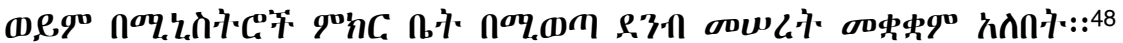

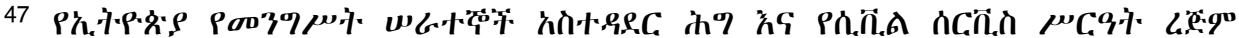
小 FАत

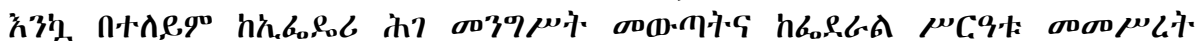

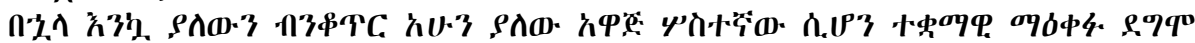

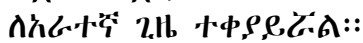

48 กhC

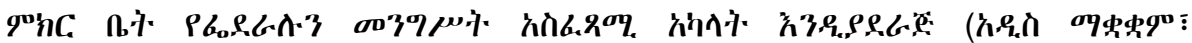

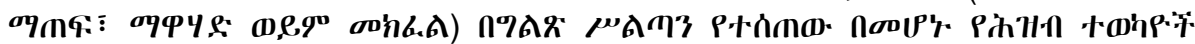

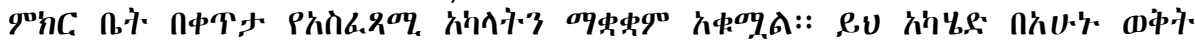
w

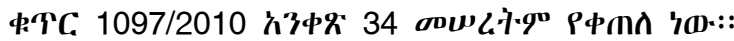




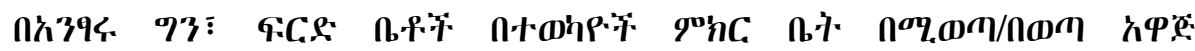

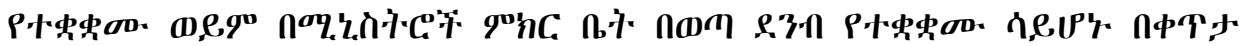

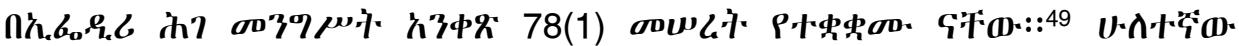

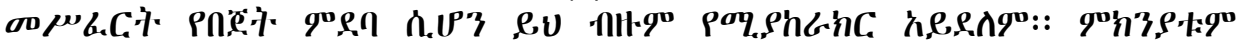

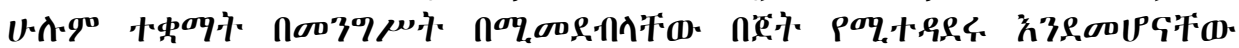

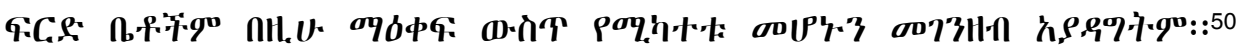

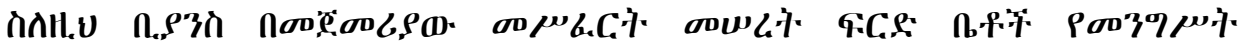
ор eUGA::

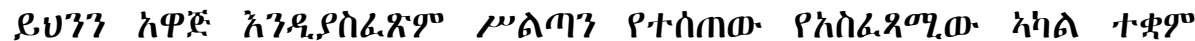

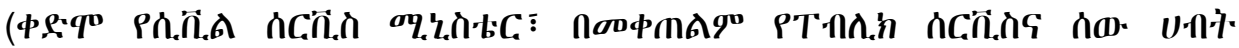

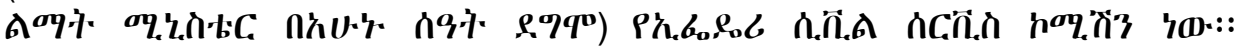

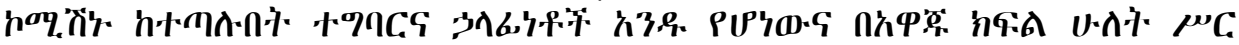

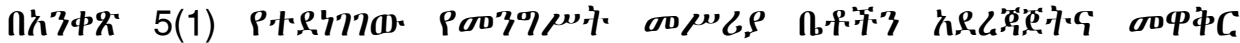

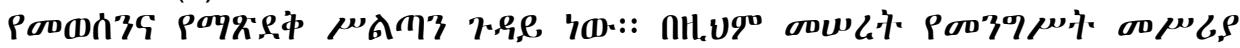

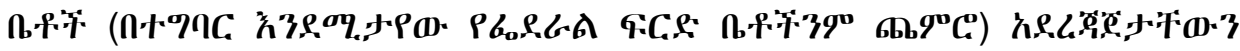

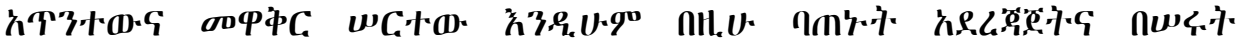

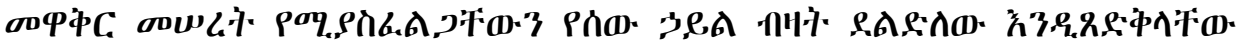

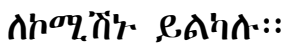

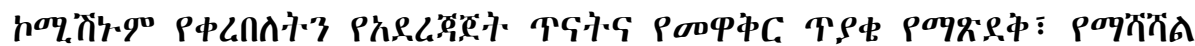

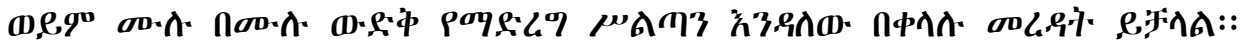

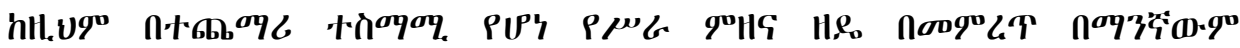

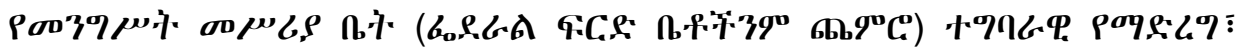

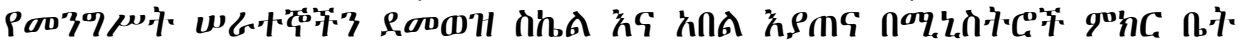

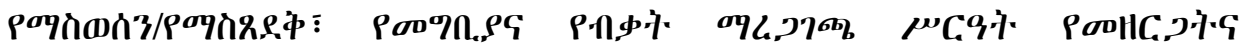

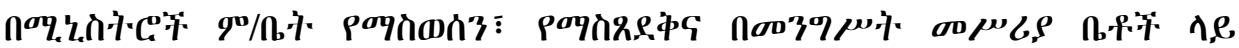

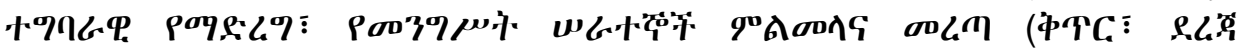

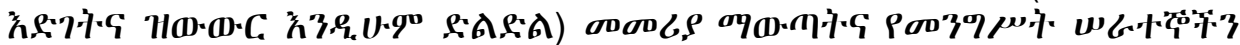

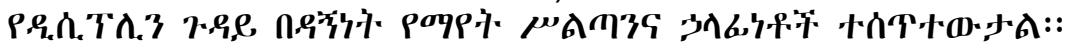

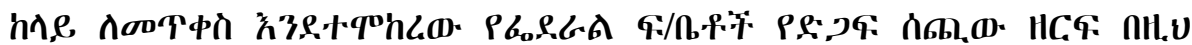

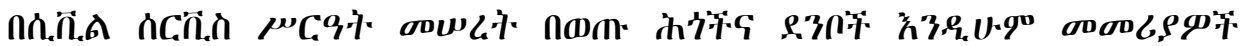

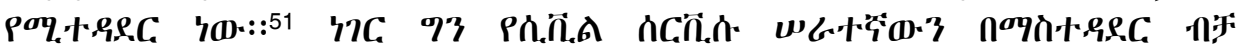

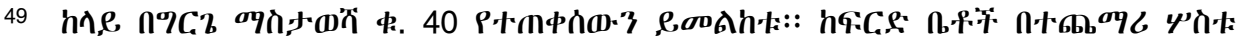

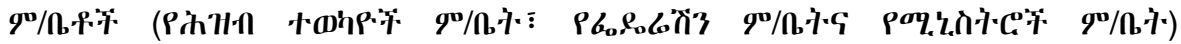

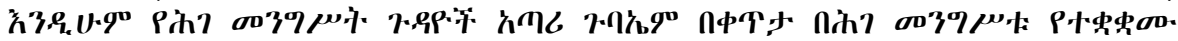

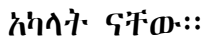

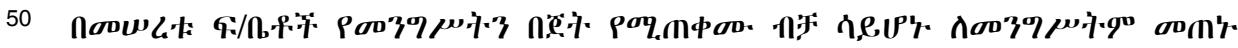

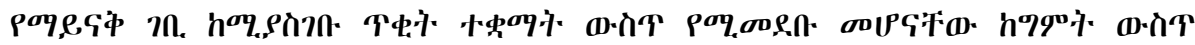

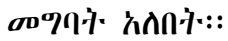

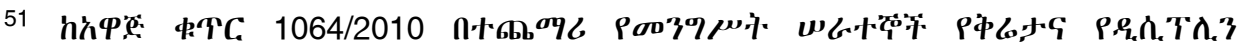

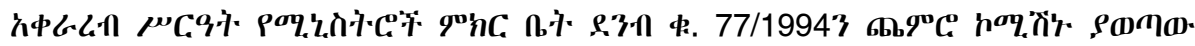




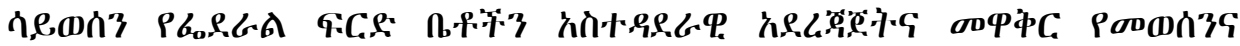

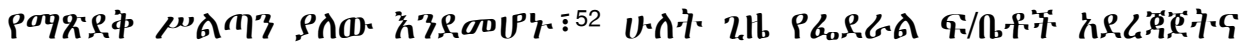

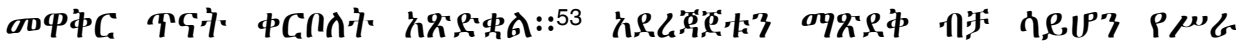

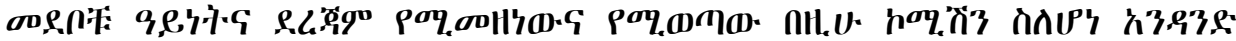

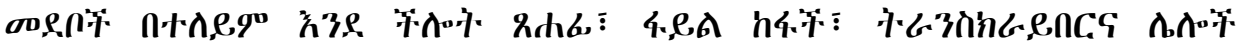

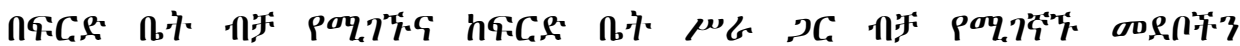

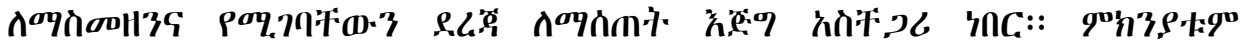

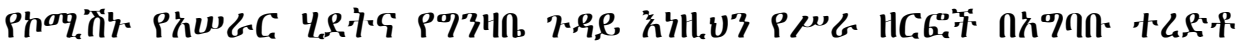

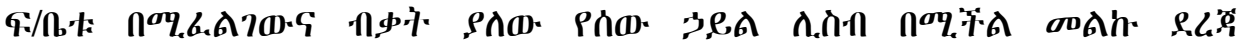

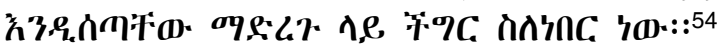

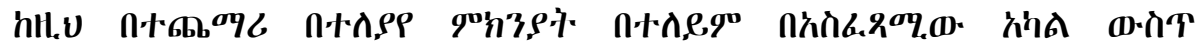

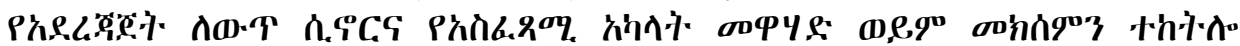

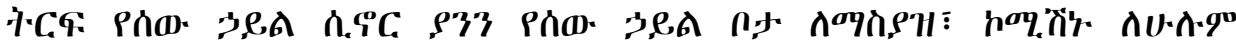

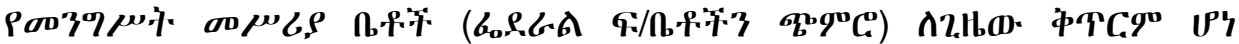

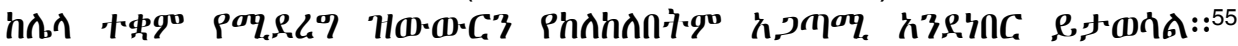

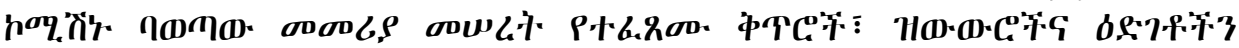

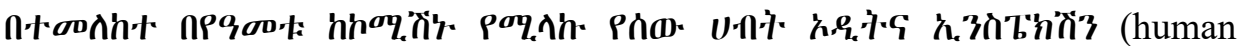

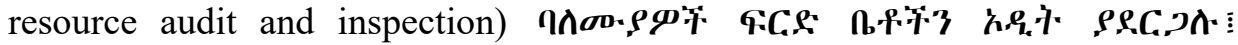

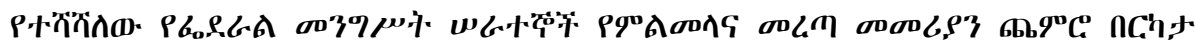
$\sigma 0 \sigma 0, \rho g$ 等

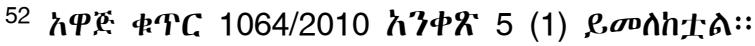

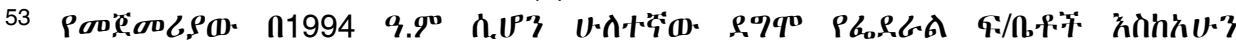

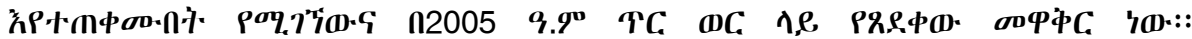

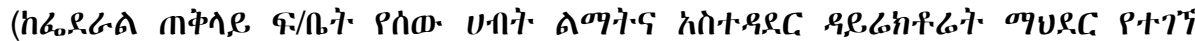
$\sigma 0(\%)$

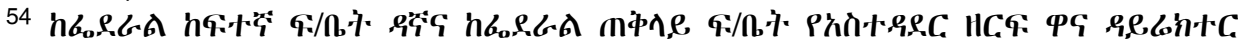

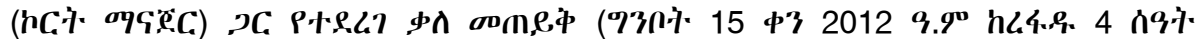

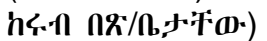

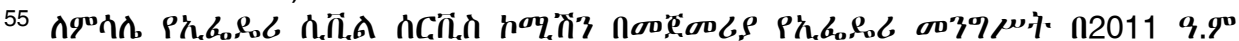

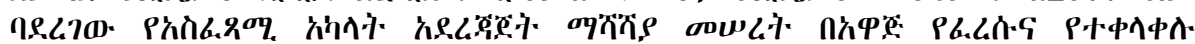

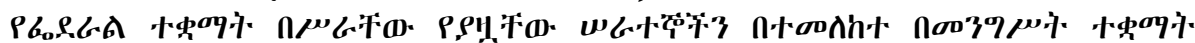

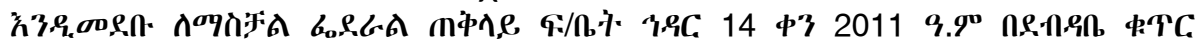

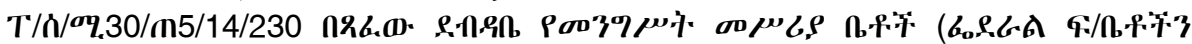

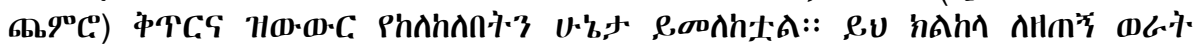

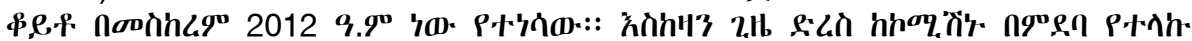
2 Ud

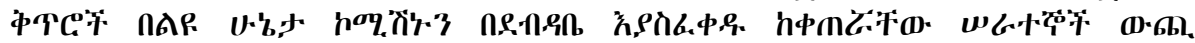

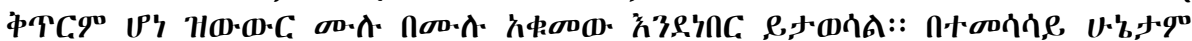

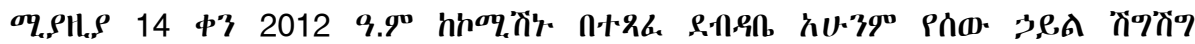

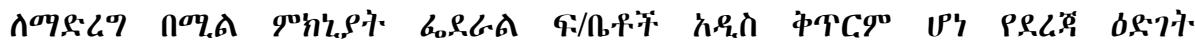

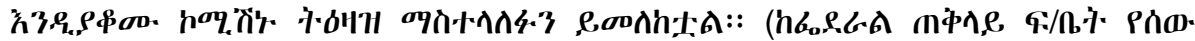

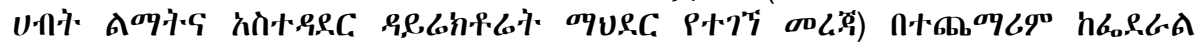

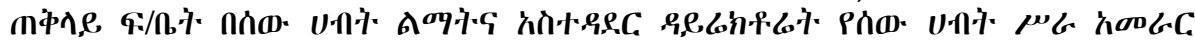

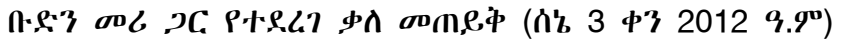




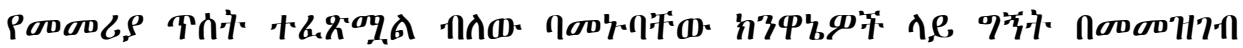

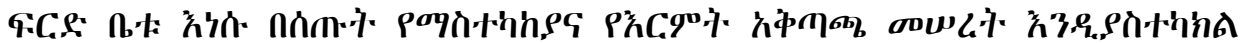

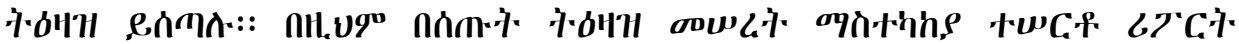

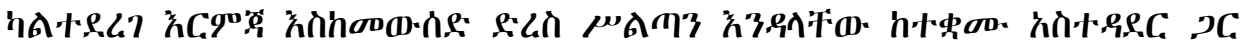

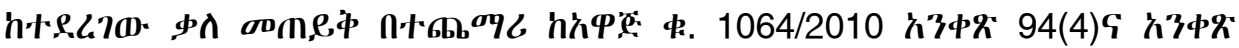

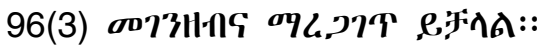

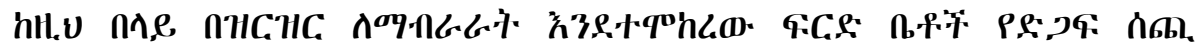

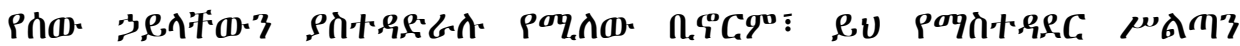

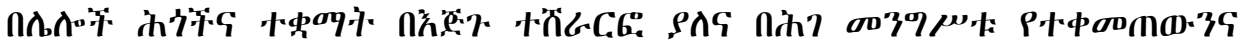

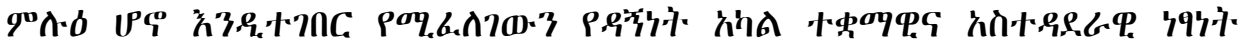

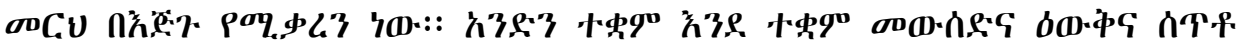

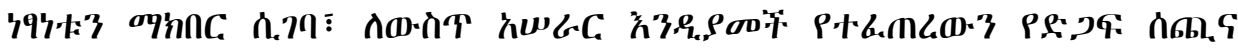

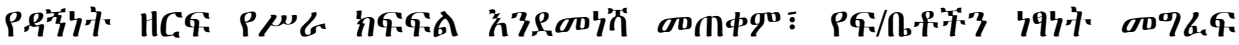

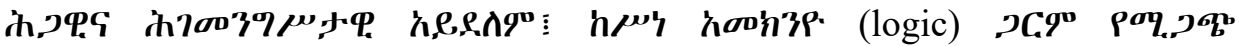
ל่าน.:

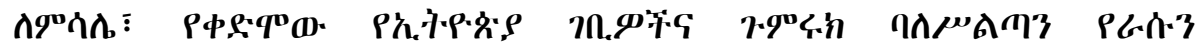

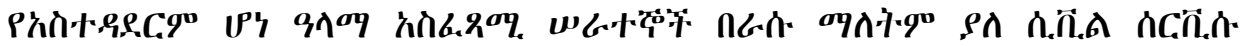

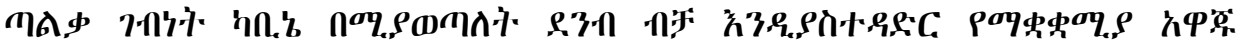

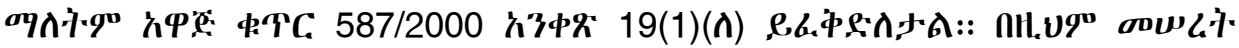

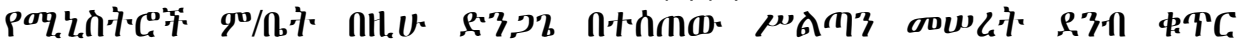

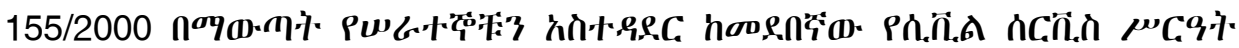

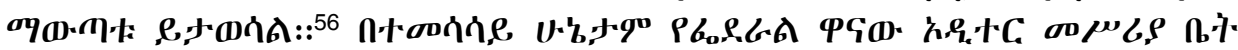

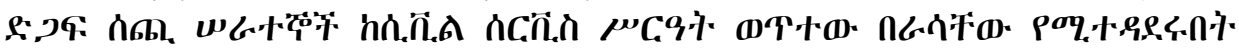

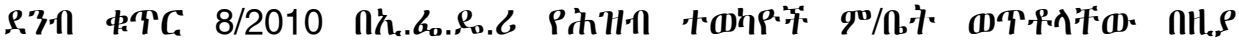

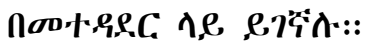

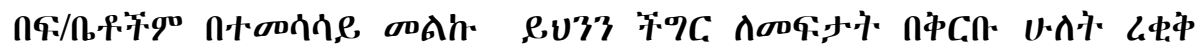

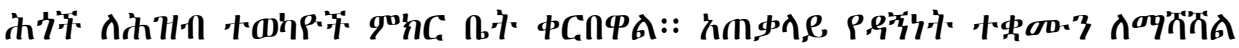

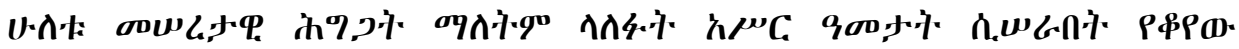

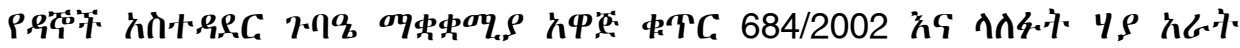

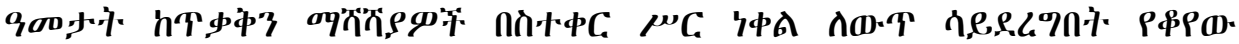

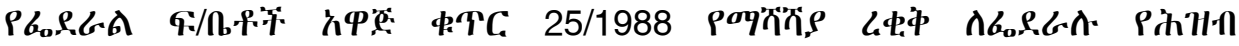

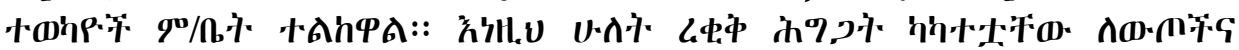

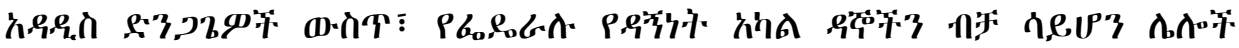

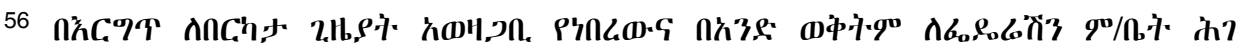

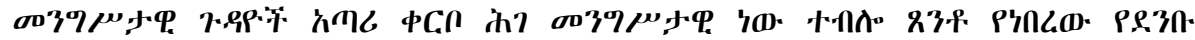

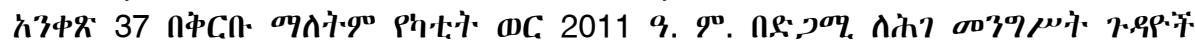

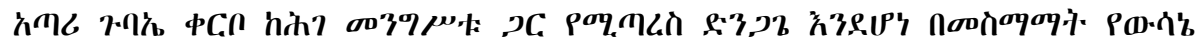

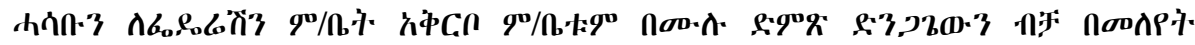

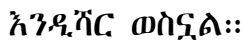




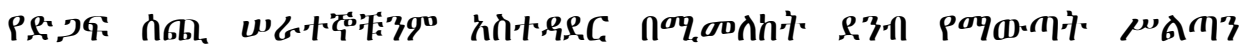

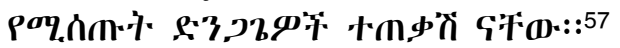

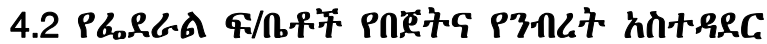

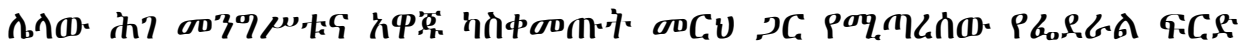

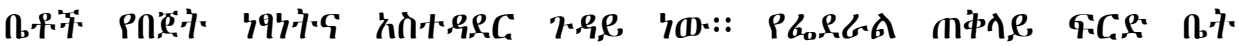

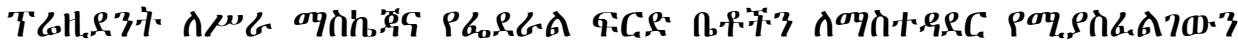

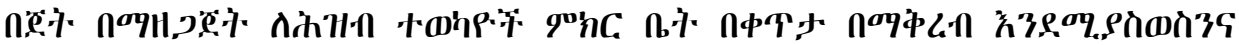
n.6.\$.9.9 ח

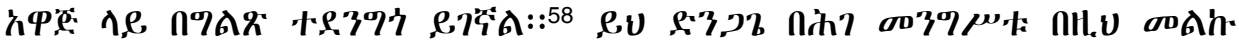

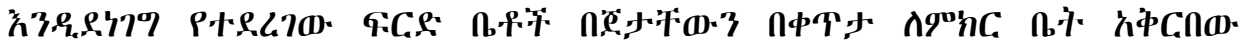

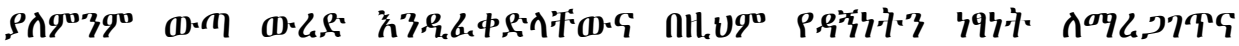

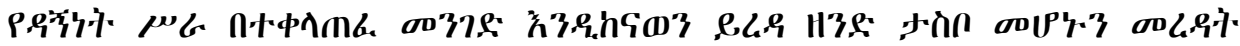

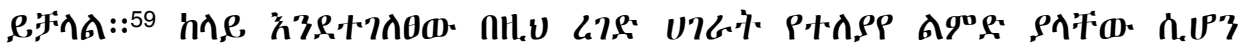

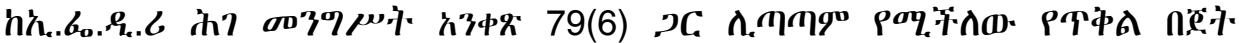
hb.,中中: (consolidated fund/budget) तों

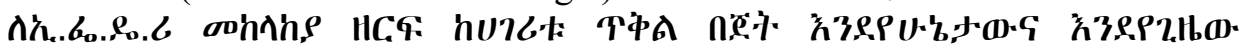

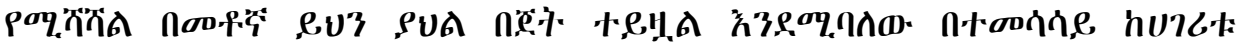

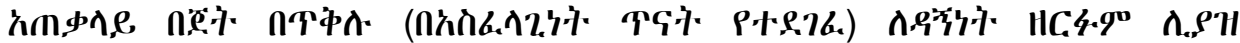
poq.790.

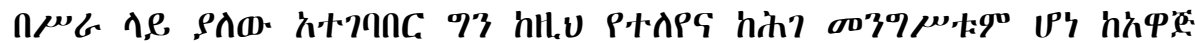

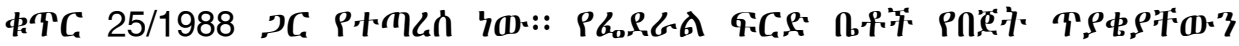

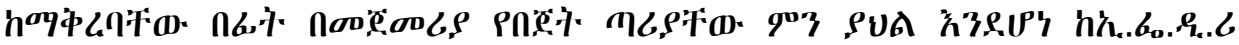

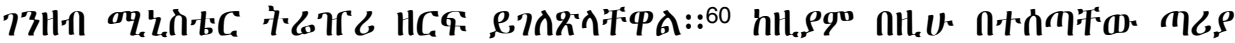

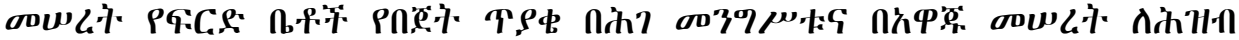

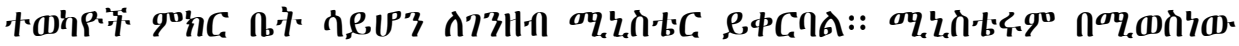

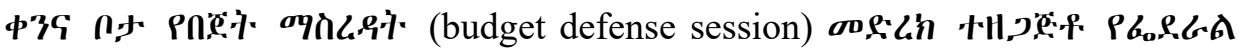

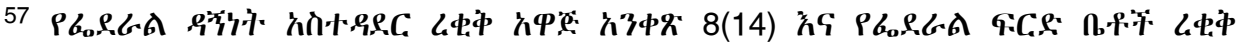

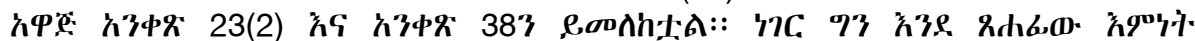

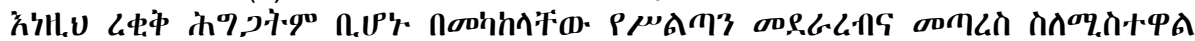

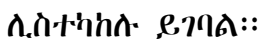

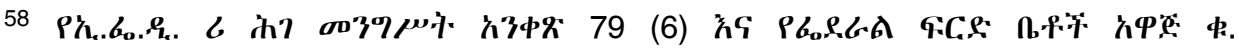

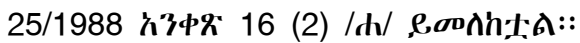

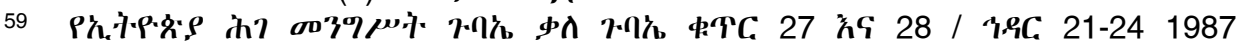

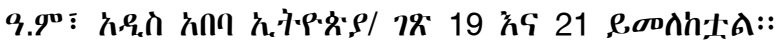

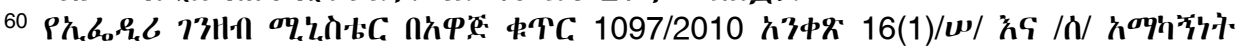

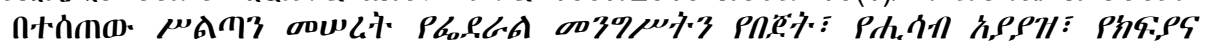

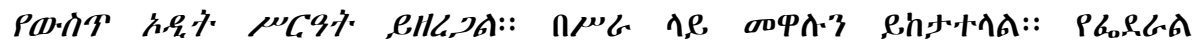

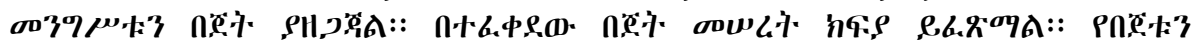

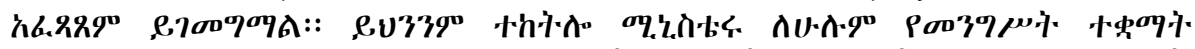

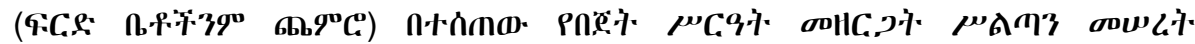

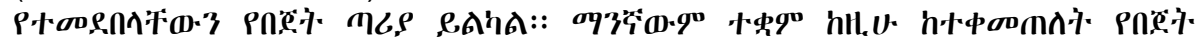

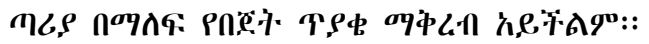




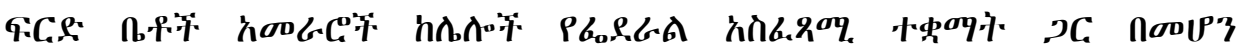

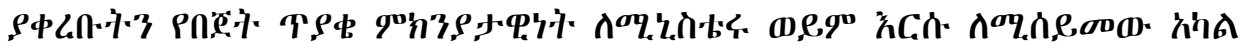

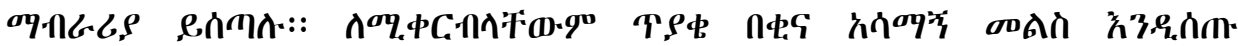

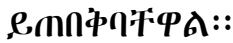

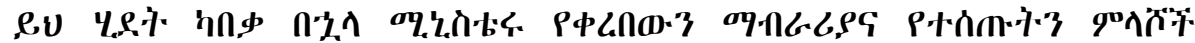

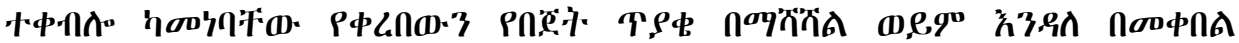

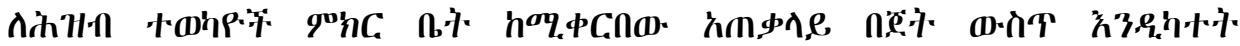

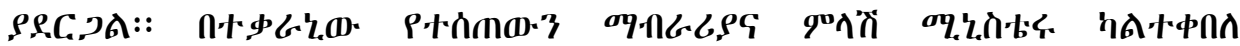

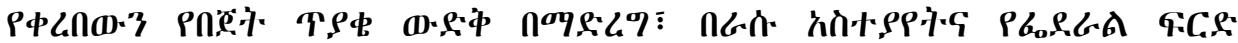

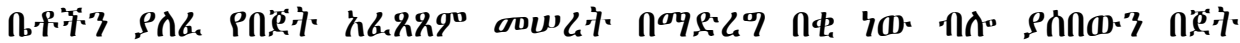

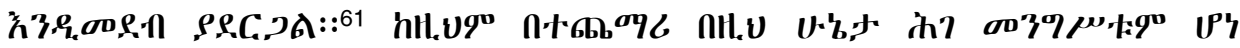

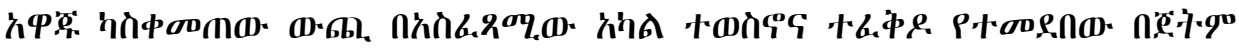

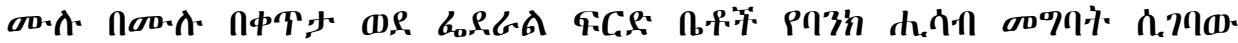

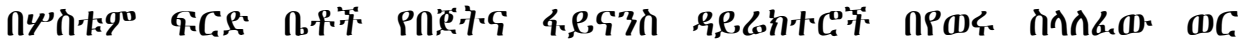

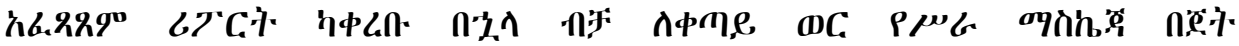

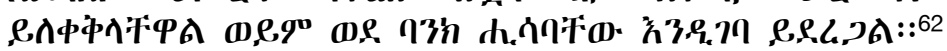

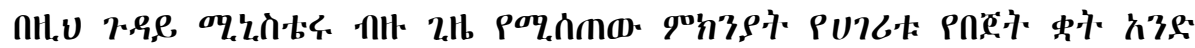

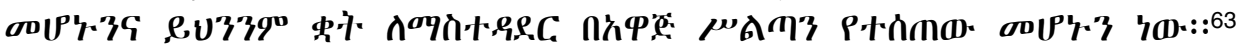

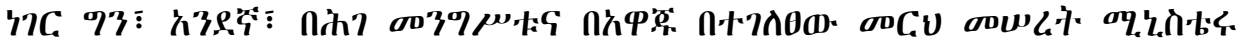

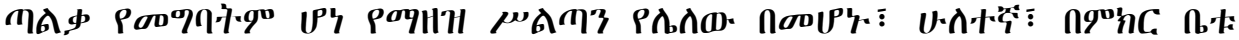

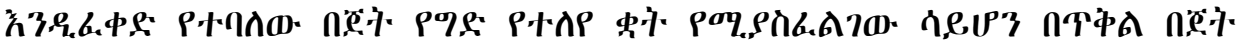

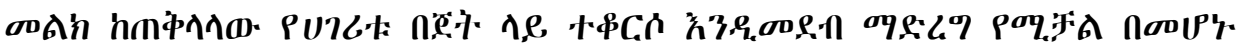

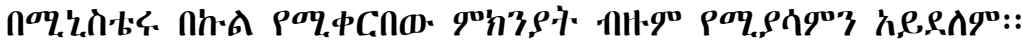

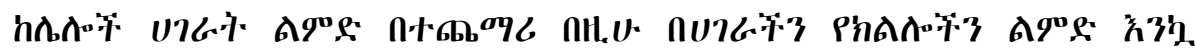

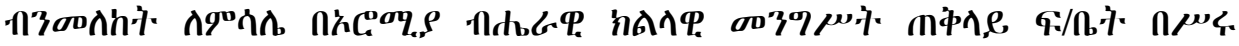

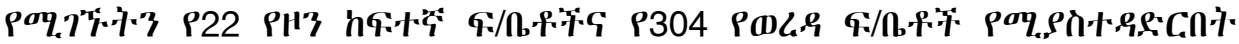

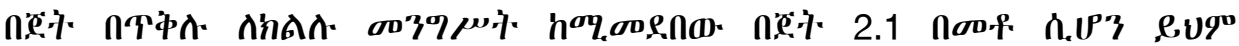

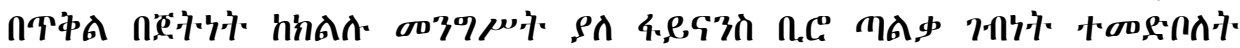

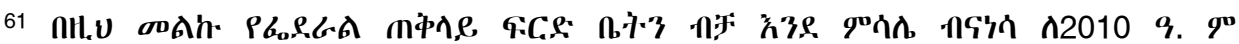

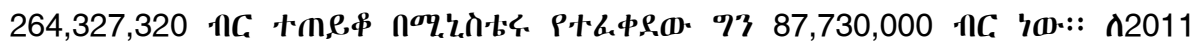

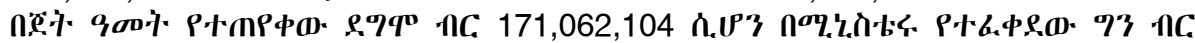

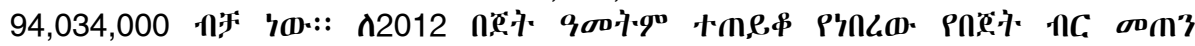

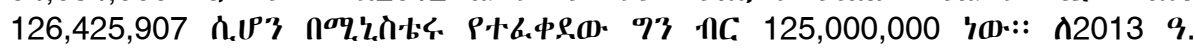

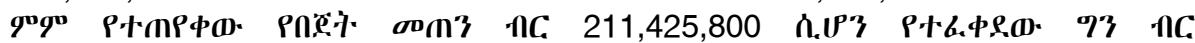

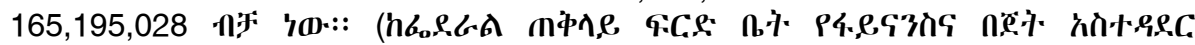

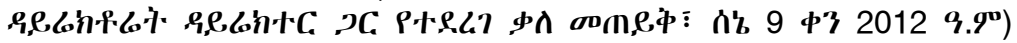

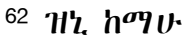

63 T'. $h^{\sigma 09}$. 


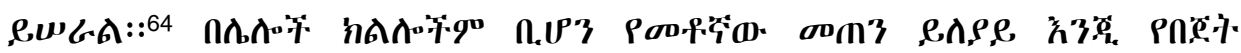

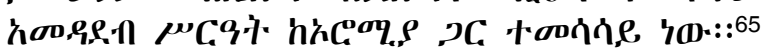

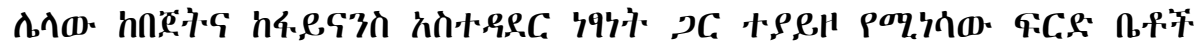

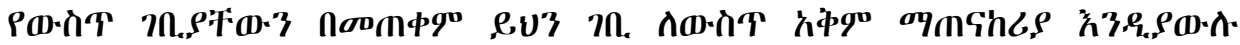

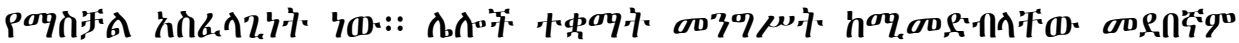

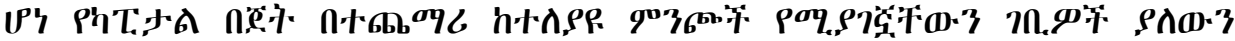

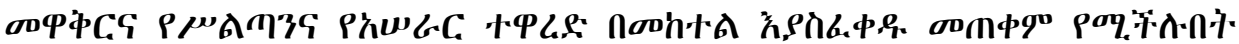

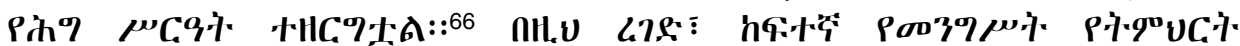

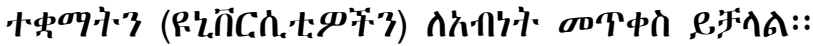

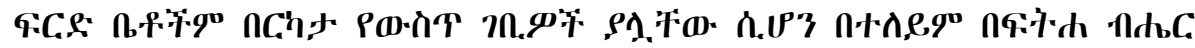

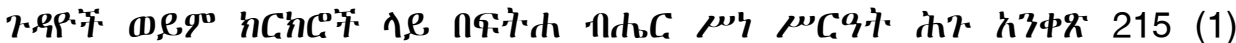

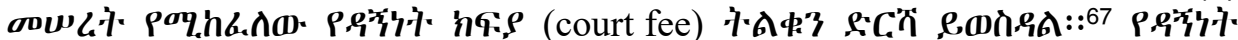

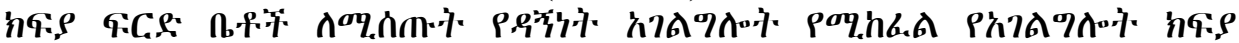

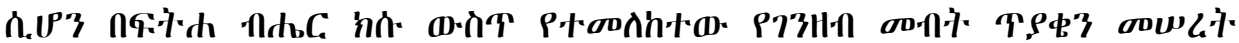

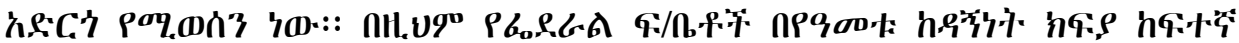
7ח.

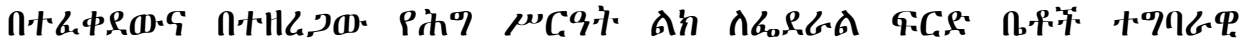
hA+PLIT":

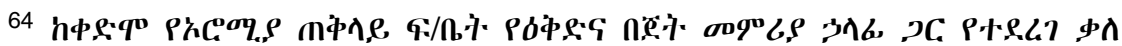
oxח,

65 H't $h^{\circ 9 y}$.

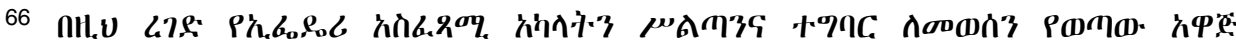

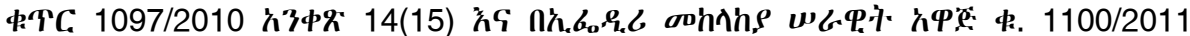

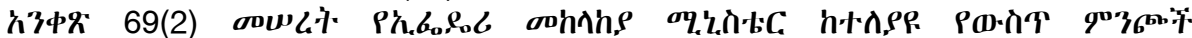

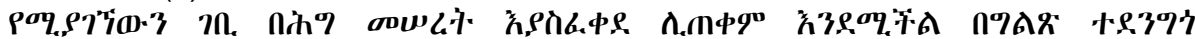

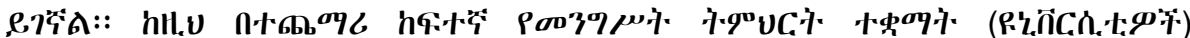

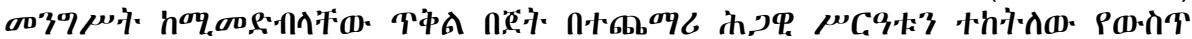

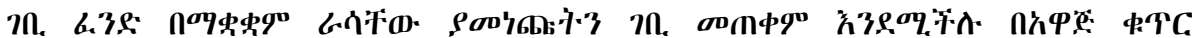

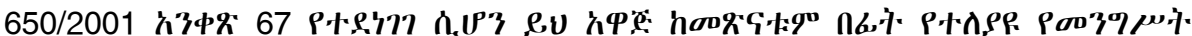

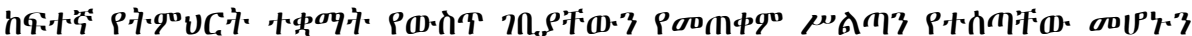

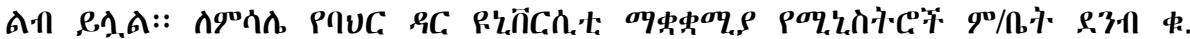

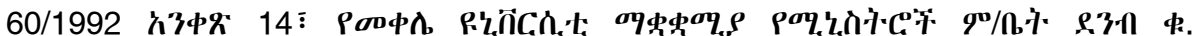

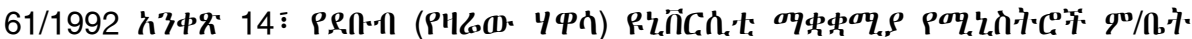

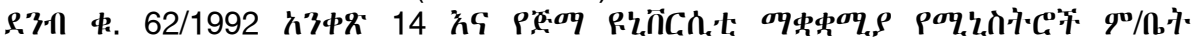

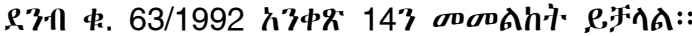

67 hH, กнњ

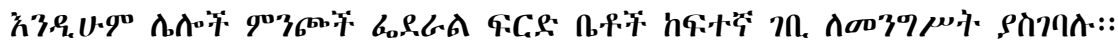

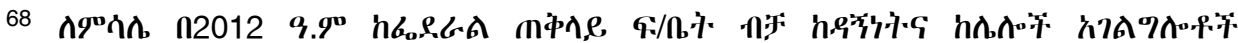

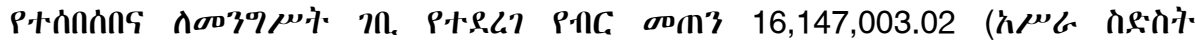

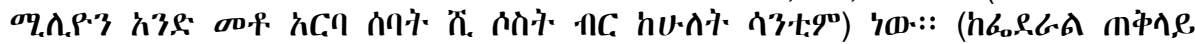

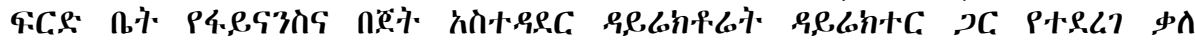
ovm, 


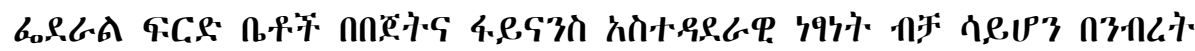

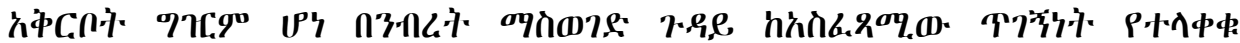
h,

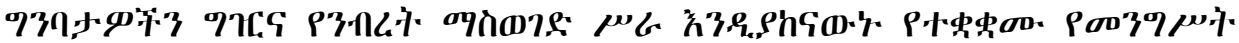

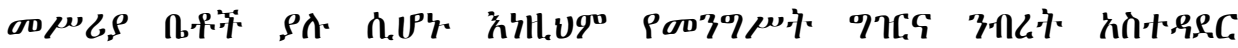
ל.

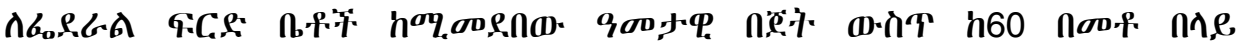
Poq.

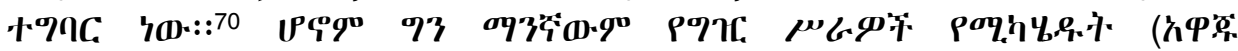

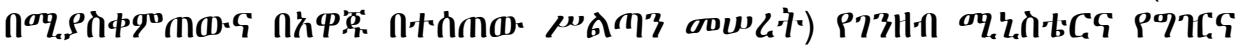

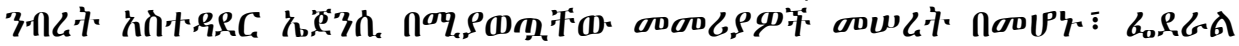
F:CS n.

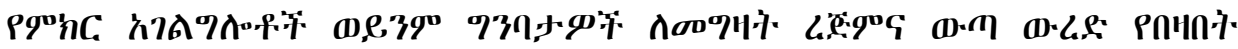

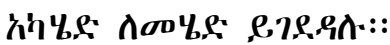

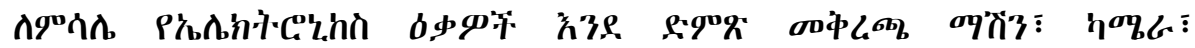

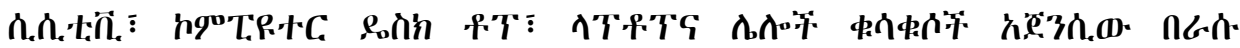

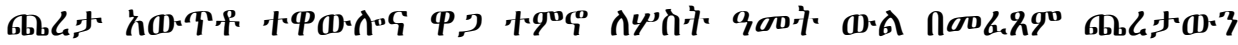

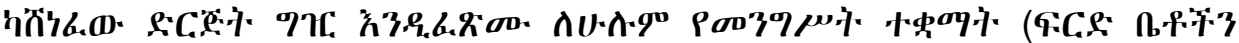

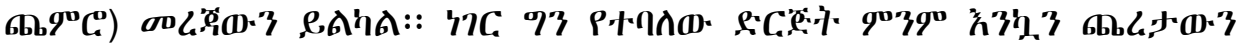

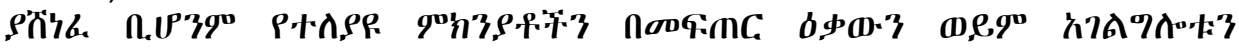

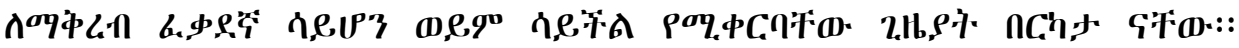
ev3390 nל.

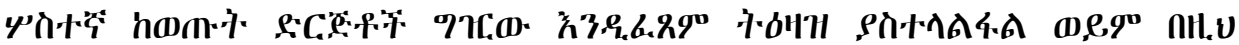

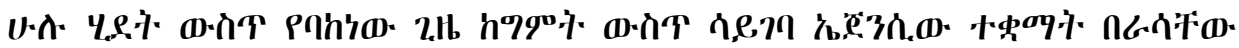

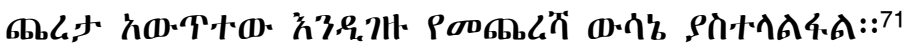

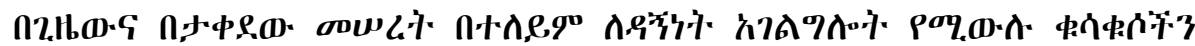

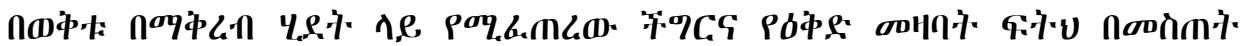
久7А

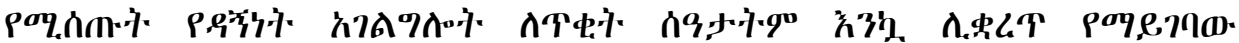
え3P.尸' \&6.

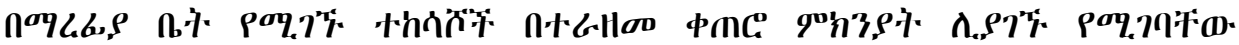

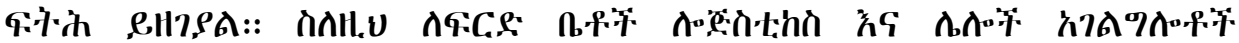
oо

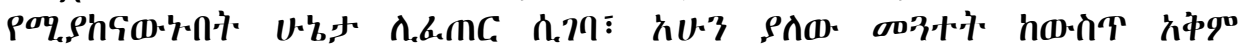

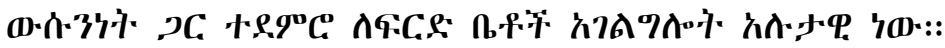

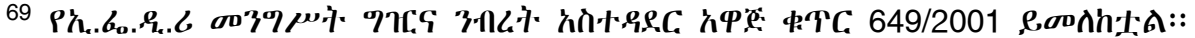

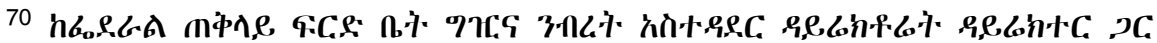

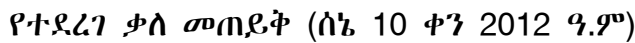

71 H' hoqu.
} 


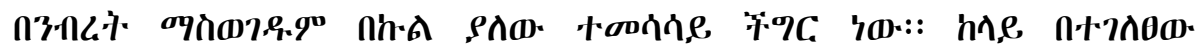

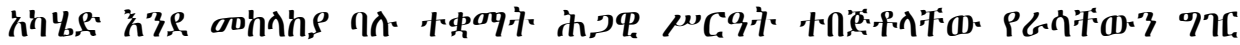

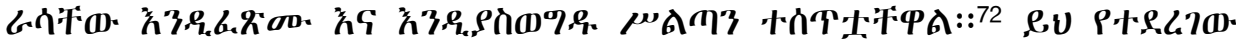

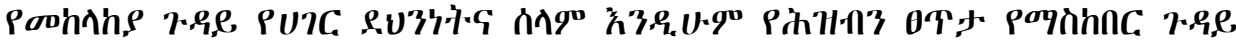

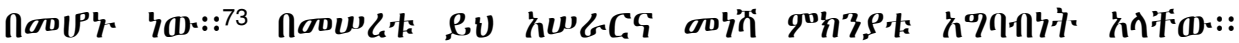

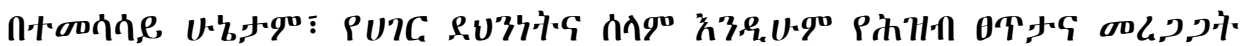

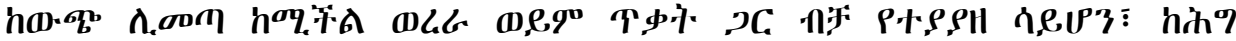

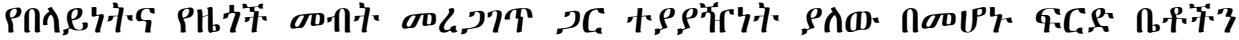

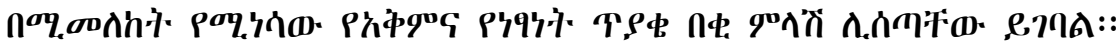

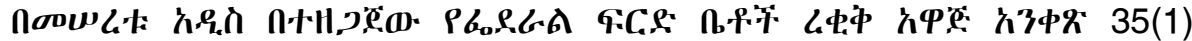

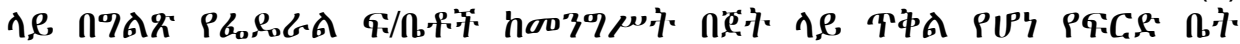

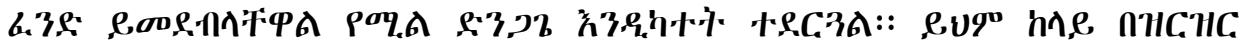

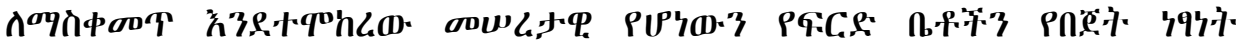

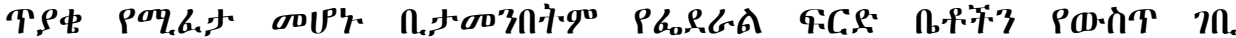

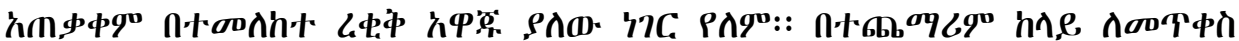

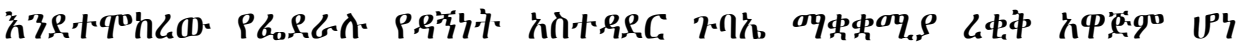

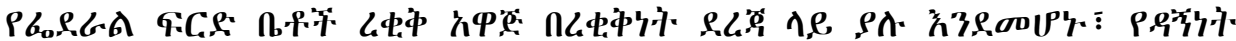

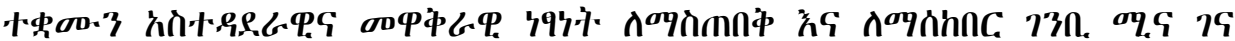

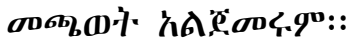

\section{3 n.}

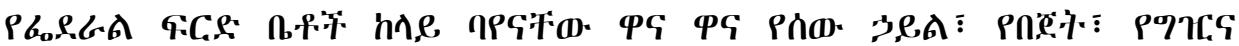

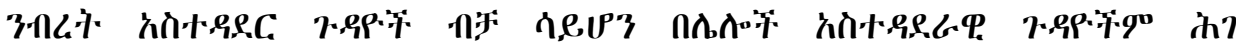

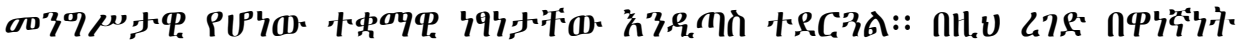

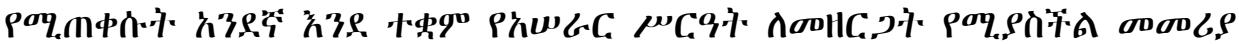

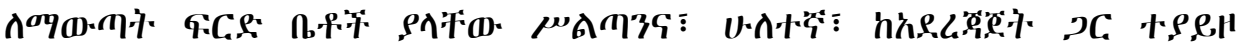

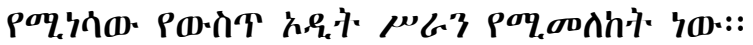

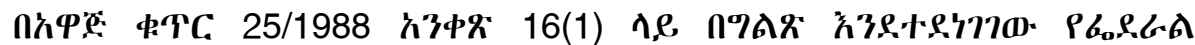

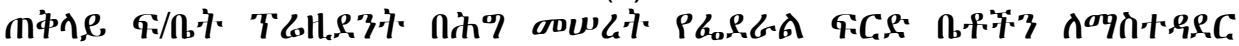

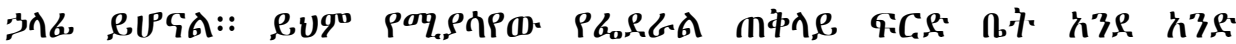

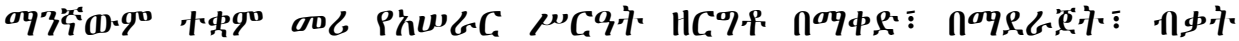

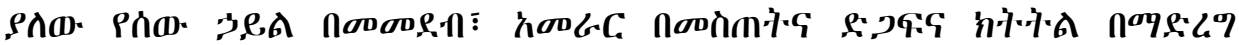

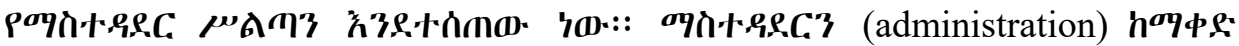

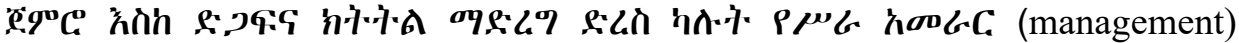

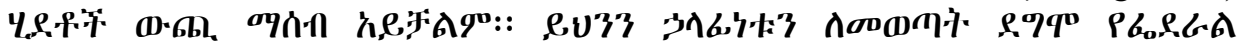

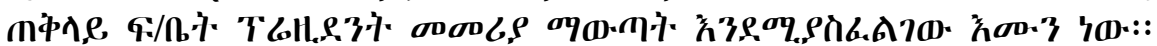

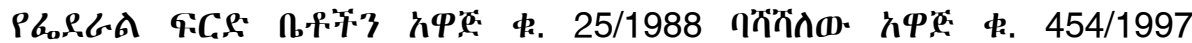

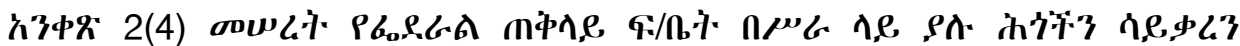

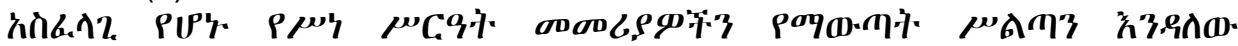

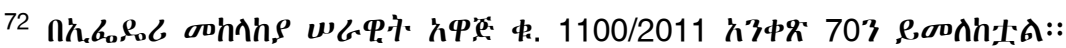

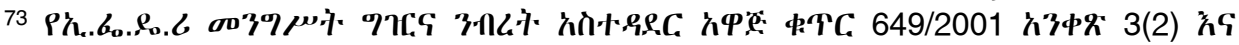

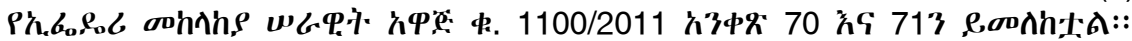




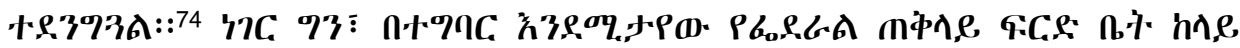

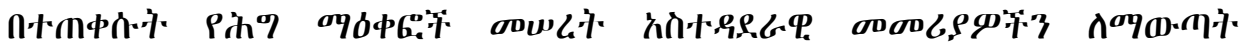

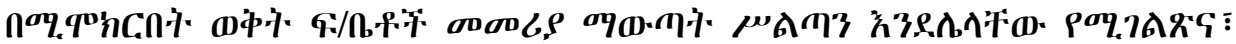

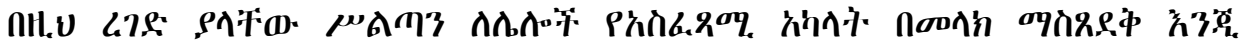

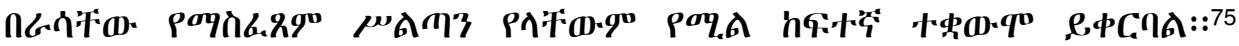

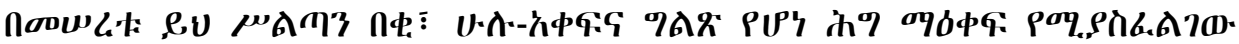

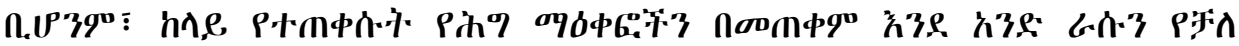

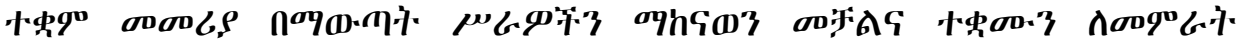

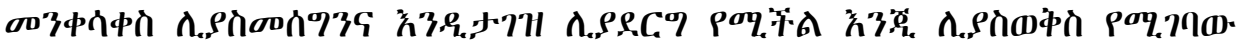
hดो

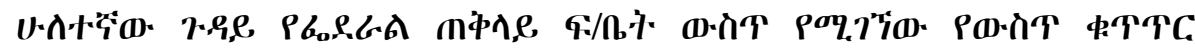

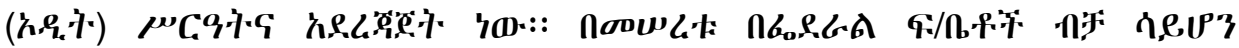

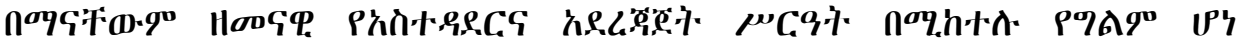

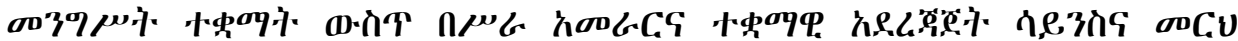
(modern organizational management science and principles) $\boldsymbol{\sigma o w} L \boldsymbol{T}$ "

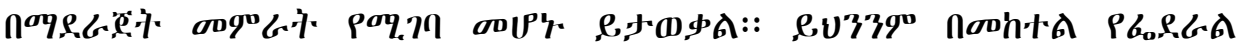

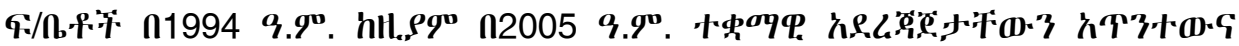

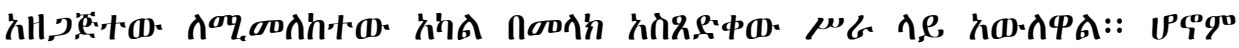

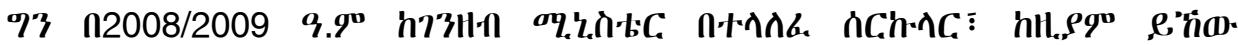

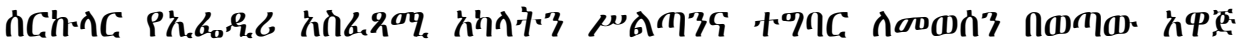

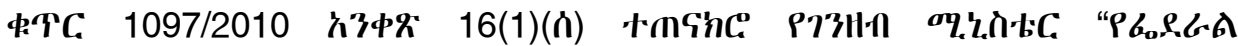

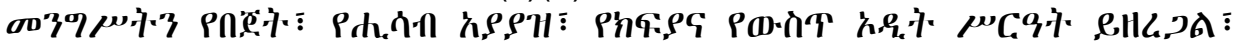

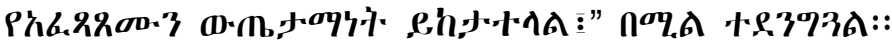

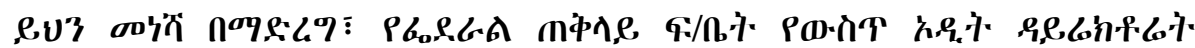

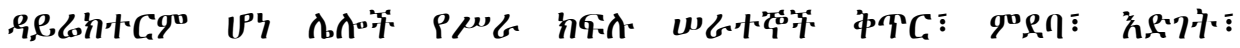

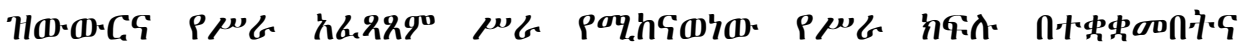

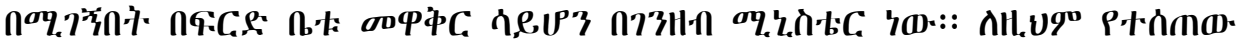

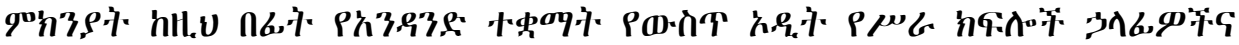

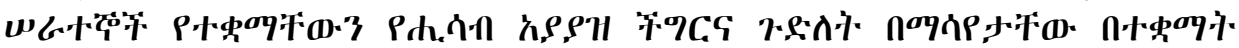

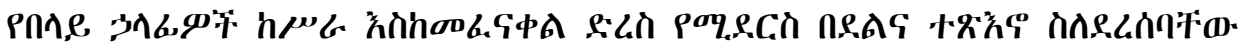

74 e औ3. 7.9p.

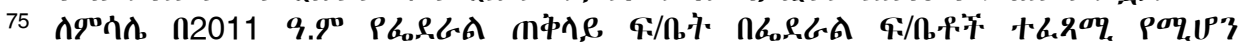

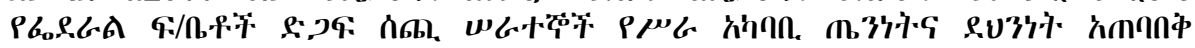

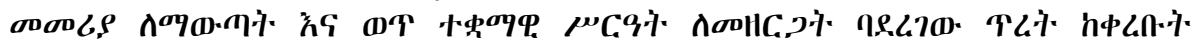

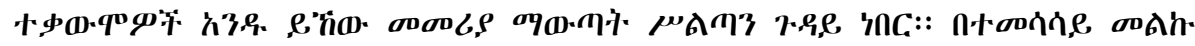

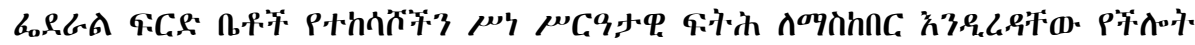

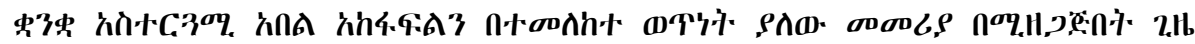

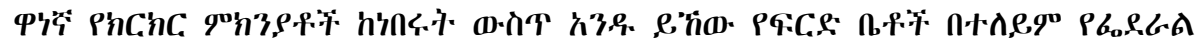

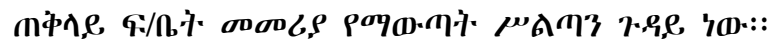




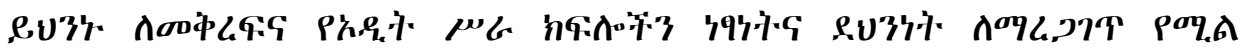
10)::

noowle Ph.

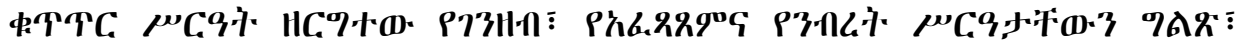

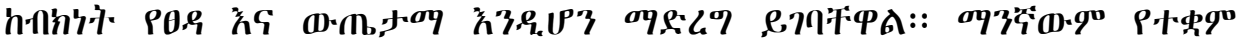

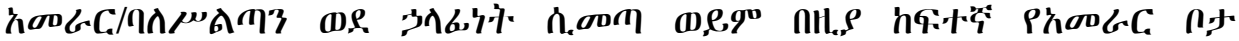

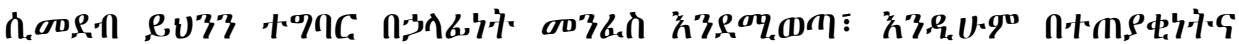

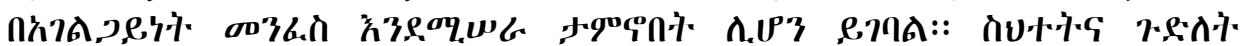

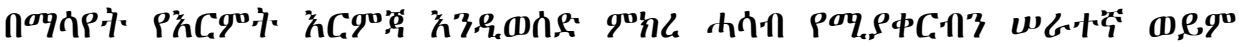

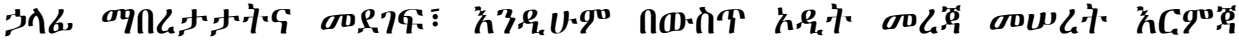

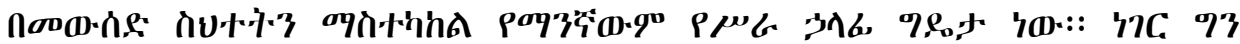

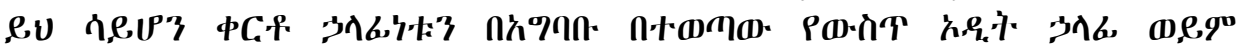

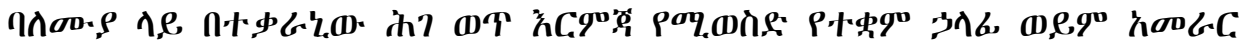

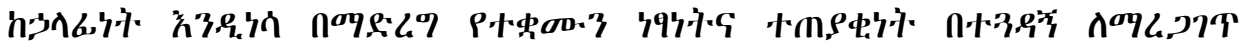

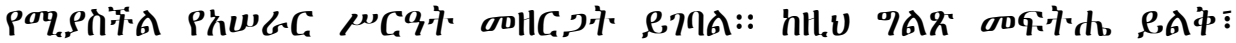

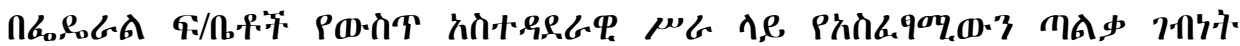

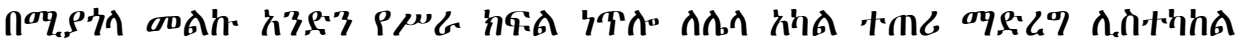
PoY.790.

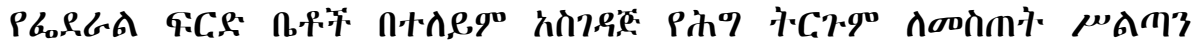

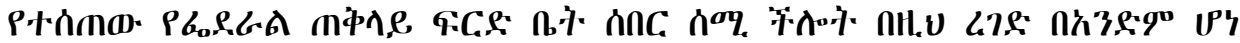

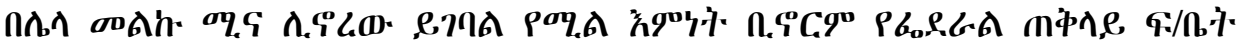

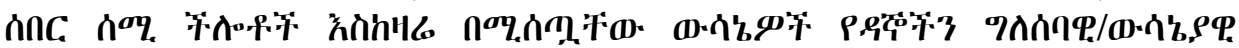

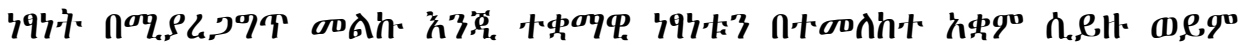

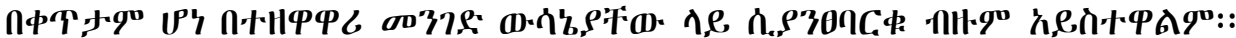

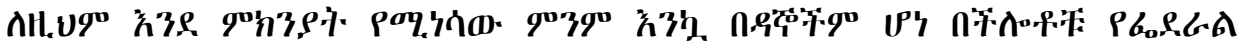

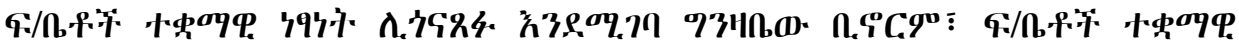

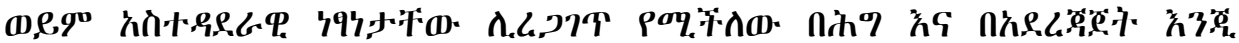

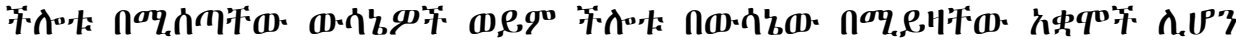
々,

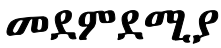

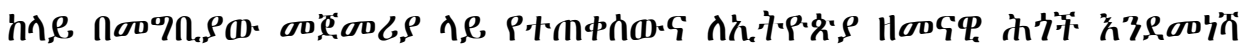

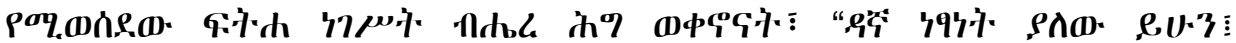

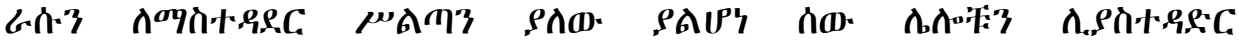
h,

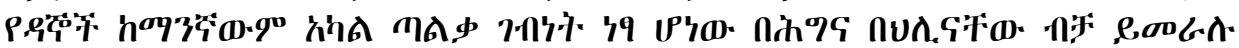

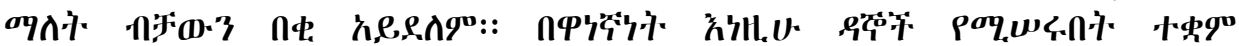

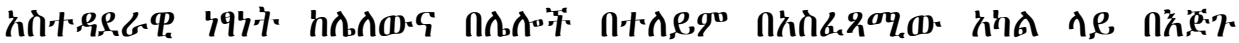

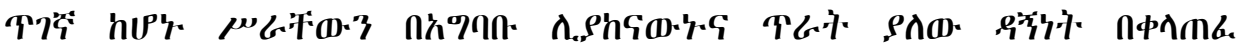

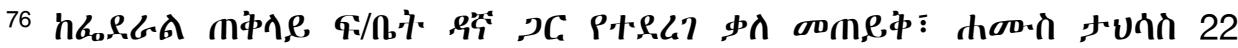
\$3 2013 9.90. 


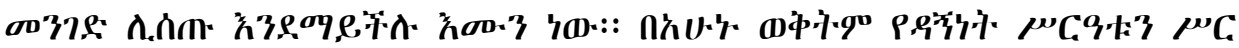

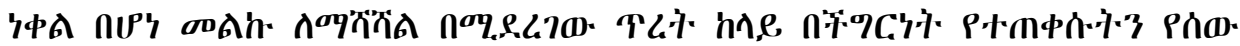

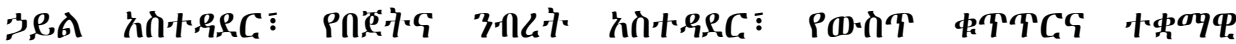

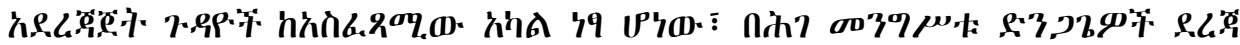

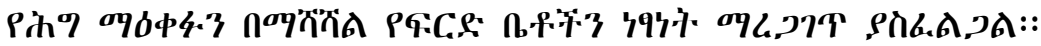

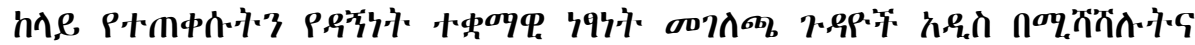

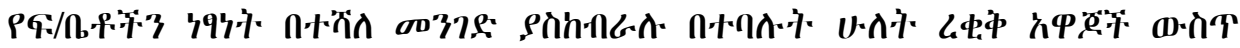

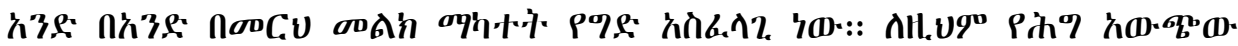

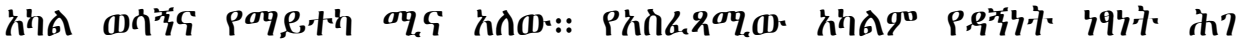

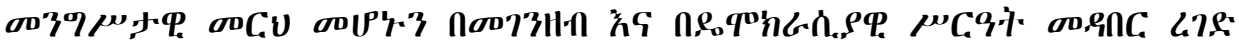

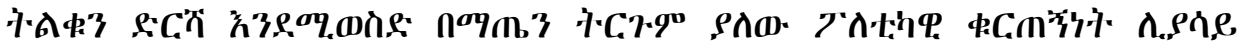

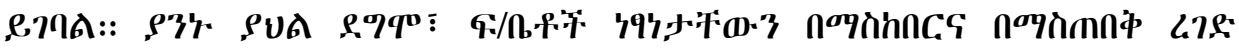

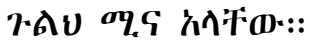

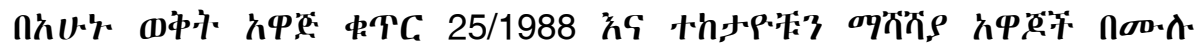

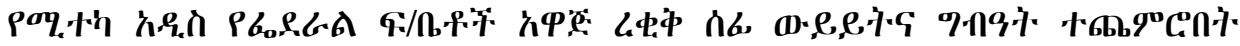

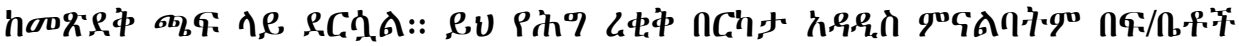

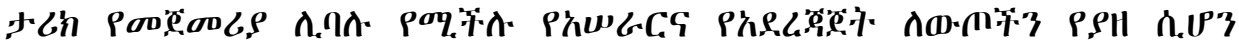

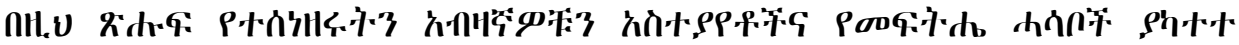

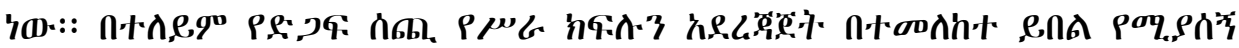

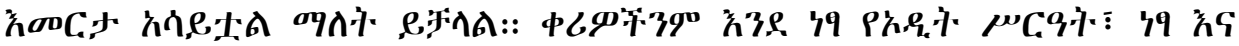

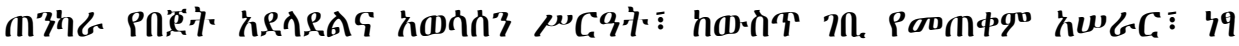

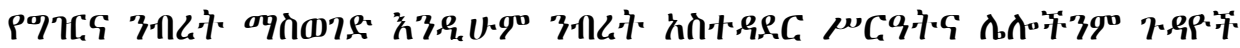

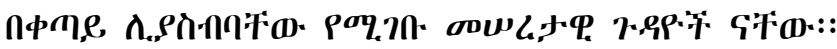

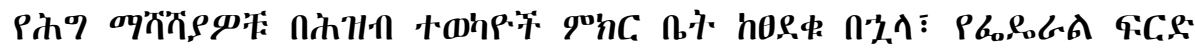

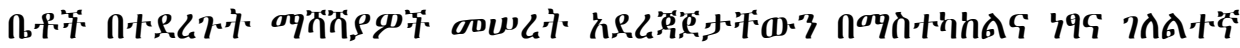

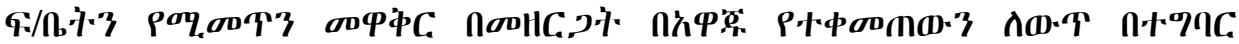

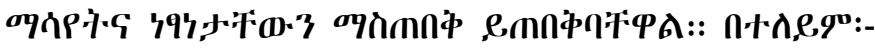

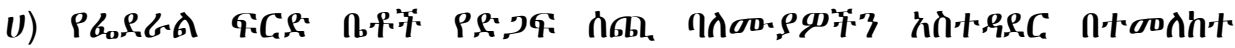

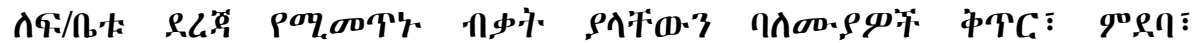

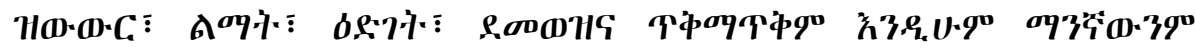

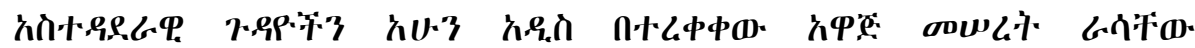

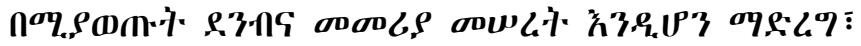

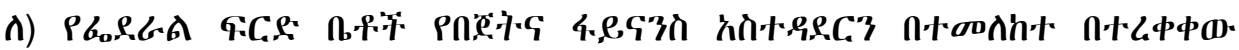
久क':

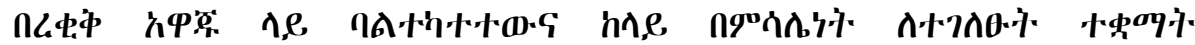

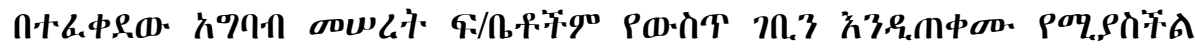

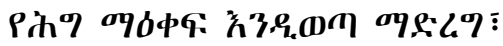

क) bo.

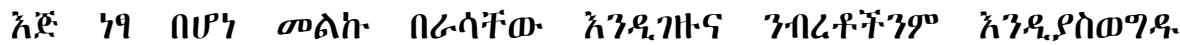

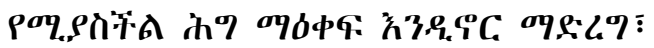

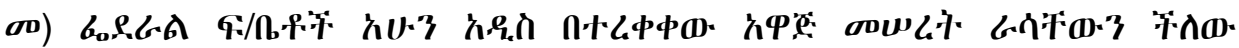

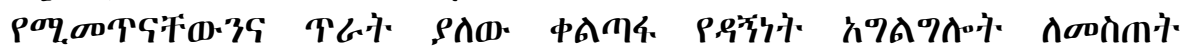




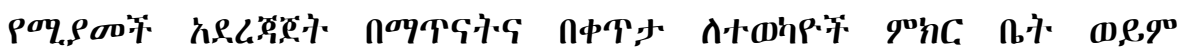
ถ

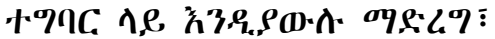

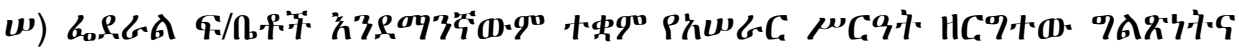

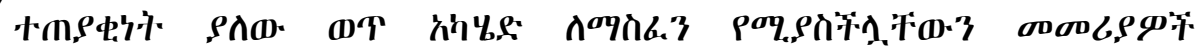
त

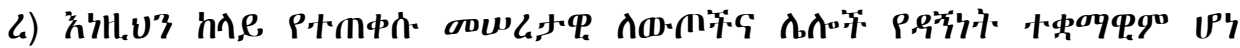

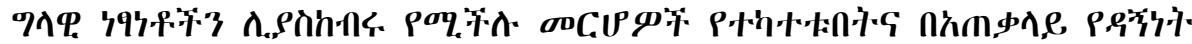

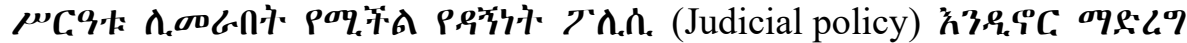

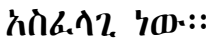

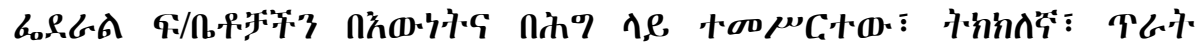

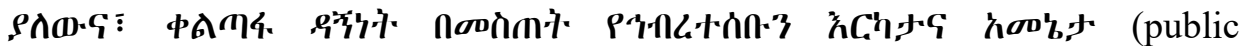

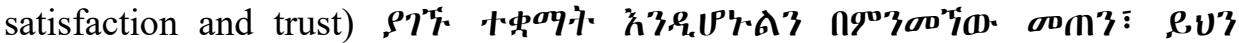

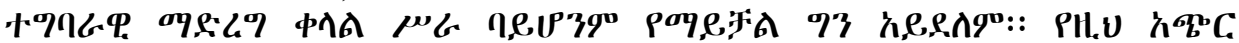

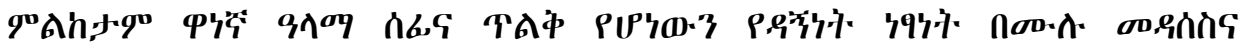

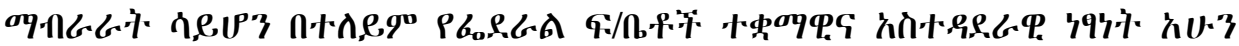
त, $90 \%$ औ

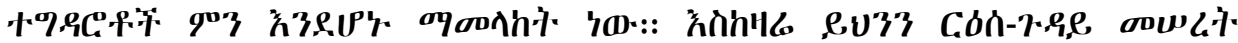

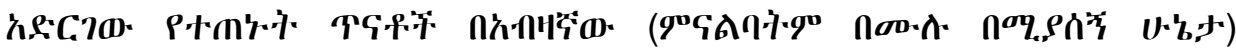

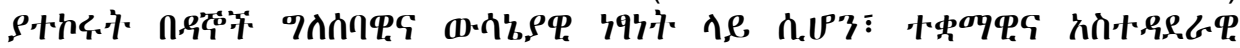

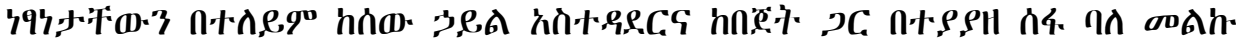

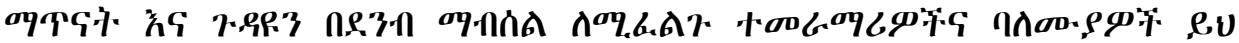
Rd.F: 